\title{
FroM BARDS TO SEARCH ENGINES: FINDING WHAT READERS WANT FROM ANCIENT TIMES TO THE WORLD WIDE WEB
}

\author{
Stephen M. Maurer*
}

Copyright theorists often ask how incentives can be designed to create better books, movies, and art. But this is not the whole story. As the Roman satirist Martial pointed out two thousand years ago, markets routinely ignore good and even excellent works. This insight reminds us that incentives to find content are just as necessary as incentives to make it. Recent social science research explains why markets fail and how timely interventions can save deserving titles from oblivion. This Article reviews society's long struggle since the invention of literature to fix the vagaries of search. The Article builds on this history to suggest policies for the emerging world of online media.

Homeric literature was produced and disseminated through direct interactions between audiences and authors. Though attractive in many ways, the process was agonizingly slow. By the first century A.D., commercial publishers had moved to the modern model of charging readers above-cost prices to pay for search and marketing. Crucially, the new model was only sustainable so long as firms could suppress copying. This Article argues that Roman and early modern publishers developed remarkably successful self-help strategies to do this. However, their methods did little to suppress copying after the first edition. This seemingly modest defect made publishers profoundly risk averse. Ancient best seller lists were invariably dominated by authors who had been dead for centuries.

Publishers' self-help systeins collapsed under a wave of piracy in the midseventeenth century. This led to the first modern copyright statutes. Crucially, these new laws extended protection beyond the first edition, empowering modern business models in which publishers gamble on a dozen titles for each that succeeds. The ensuing proliferation of titles helped fuel the Enlightenment and promoted a rich new ecosystem of search institutions including libraries, newspaper critics, and editors.

The Digital Age has changed everything. As copyright fades, the old institutions for finding titles are drying up. This Article explores several possible responses. First, society can shore up current publishing models by expanding copyright and technical protections. These methods cannot save book search, but might be adequate for music and movies. Second, search engines

* Goldman School of Public Policy, University of California at Berkeley. I thank the Sloan Foundation for their generous support and the Institute for Advanced Studies in Toulouse for hosting him as a visiting scholar in the Spring of 2013. Much of this article was written when I held a joint appointment at Berkeley Law School. The article also benefited from extensive discussions with the late Suzanne Scotchmer. I also thank Reiko Aioki, Rochelle Dreyfus, Rebecca Eisenberg, Nancy Gallini, Tom Hendrickson, Joachim Henkel, Chris Hoofnagle, Alex Karepetian, Rob Merges, Randall K. Morck, Ricky Revesz, Pam Samuelson, Mark Schankerman, and Paul Seabright for many helpful comments. 
could pay for editors. This Article argues that an on-line digital bookstore can suppress copyists long enough to fund reasonable search efforts. Finally, society can return to the Homeric pattern of harvesting advice directly from audiences. This Article explores various commercial and open source institutions for organizing the work.

I. INTRODUCTION 497

II. The SEARCH Problem

A. The Challenge

B. Beyond Computer Models

C. Doing Better: The Role of Institutions

1II. The First Age of SEARCH: A World Without PRINTING .................... 504

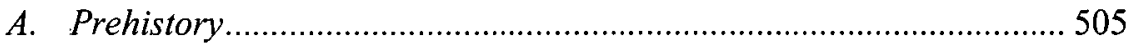

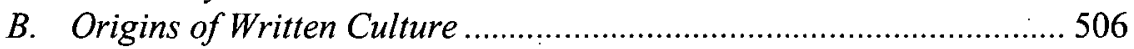

C. The First Commercial Publishers. ................................................... 507

D. Was Ancient Search Efficient? ............................................ 511

IV. THE SECOND AgE OF SEARCH: PrINTING ......................................... 514

A. Medieval Publishing................................................................... 514

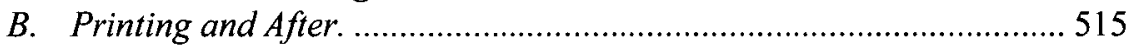

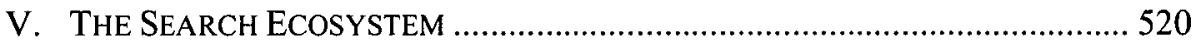

A. Publishers and Editors .......................................................... 520

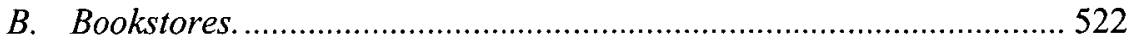

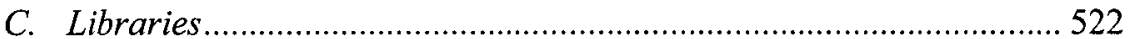

D. Third Party Influencers: Governments, Aristocrats, Scholars, and

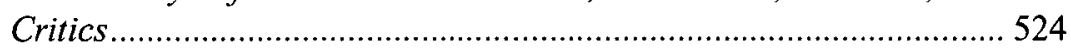

VI. THE THIRD AGE OF SEARCH: THE STORY SO FAR.................................. 525

A. Reconnecting With Audiences ..................................................... 525

B. Vanishing Physical Costs ............................................................... 527

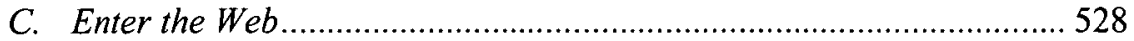

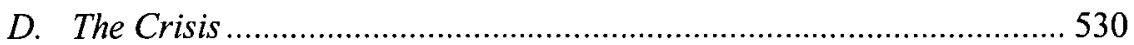

VII. THE WAY FORWARD .......................................................................... 531

A. Defending Today's Publishing Model: The Limits of Technical Protection.................................................................................... 532

B. The Return of Self-Help: Digital Bookstores .................................... 533

C. The Radical Solution: Replacing Editors....................................... 536

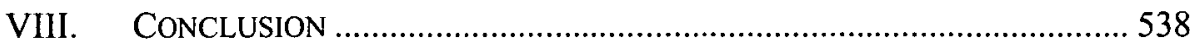




\section{INTRODUCTION}

Copyright theorists normally focus on incentives for creating new books, music, and movies, but this is only half the battle. A successful copyright system must also find content that people want and convince them to try it. ${ }^{1}$ Society has invented dozens of institutions for doing this since Roman times. But the record is spotty. If anything, the available evidence suggests that consumers' ability to find content is declining.

Part II describes the search problem in detail, focusing on generic obstacles that have remained surprisingly constant since Roman times. Parts III through VI describe society's attempts to solve these problems over the past two thousand.years. Part VII asks what today's on-line markets can learn from history. Part VIII presents a brief conclusion.

\section{The SEARCH PROBLEM}

In theory, mankind's access to information has never been better. Ten years ago, most of the world's books were only available in universities or through tedious interlibrary loan requests. Today, much of this material can be downloaded by anyone with an Internet connection. ${ }^{2}$ Access is worthless, however, unless one knows for what to ask for. This section describes the search problem and asks how well word of mouth networks - the default solution in any organized society - actually work.

\section{A. The Challenge}

Humankind has accumulated 129 million separate book titles since Gutenberg. ${ }^{3}$ Commercial film and video have generated an additional 200,000

1. Cf. Richard B. Sher, ThE EnLightenment \& THE BoOK 26 (2006) (complaining that copyright theory has developed a "preoccupation with the reprinting of old books by dead authors and a failure to appreciate the more innovative, and often more cooperative activities of the book trade in the publication of new books.").

2. Many post- 1923 books remain unavailable for copyright reasons. $C$ f. Authors Guild v. Google, 770 F.Supp.2d 666, 670, 682, 686 (S.D.N.Y. 2011) (rejecting proposed settlement which would have required copyright holders to opt out of scanned book sales program). Fixing this will almost certainly require legislation. In the meantime, the situation is slowly improving as publishers convert backlisted titles to e-books and Alibris helps consumers search for used physical copies across 12,000 stores. CHRIS ANDERSON, THE LONG TAIL 87 (2006).

3. Jean-Baptiste Michel et al., Quantitative Analysis of Culture Using Millions of Digitized Books, 331 SCIENCE 176, 177 fig.1 (2011). See also Robert Lee Hotz, The World-Wide Web Launches: New Google Database Puts Centuries of Cultural Trends in Reach of Linguists, WALL ST. J., Dec. 17, 2010, http://online.wsj.com/articles/SB100014240527487040738045760237418499 22006. About one million new titles are published each year. Robert Darnton, The Library: Three Jeremiads, N.Y. REV. BOOKS, Dec. 23 2010, available at http://www.nybooks.com/articles/archives $12010 / \mathrm{dec} / 23 /$ library-three-jeremiads. U.S. authors account for about one-third of the total and published an estimated 288,355 new titles in 2009. Bowker Reports Traditional U.S. Book 
titles. ${ }^{4}$ Popular music data is less certain, but include at least two million titles from the twentieth century. ${ }^{5}$

Formally, at least, this material has never been more accessible. Google Books offers more than thirty million scanned volumes. ${ }^{6}$ Informal checks suggest that the collection is remarkably complete even for hard-to-find titles. While Google's material is mostly in English, many countries are funding programs to fill the gap for other languages. ${ }^{8}$

The bottom line is that individuals will soon live in a world where everything that humans have ever published, filmed, painted, or recorded is eternally present. ${ }^{9}$ Hemingway once said "the good writer competes only with the dead." 10

Production Flat in 2009, BOWKER (Apr. 14, 2010), http://www.bowker.com/enUS/

aboutus/press_room/2010/pr_04142010.shtml. The corresponding figure for movies is much lower: just 535 new movies were screened in the U.S. in 2010. Marton Mestyan et al., Early Prediction of Movie Box Office Success Based on Wikipedia Activity Big Data, 8 PLOS ONE at 2, available at http://www.plosone.org/article/info\%3adoi\%2F10.1371\%2Fjournal.pone.0071226 (citing 2010 . Domestic Grosses, BOX OFFICE MOJO (last updated Sept. 17, 2014, 3:13 PM), http://boxofficemojo.com/yearly/chart/yr=2010\&p=.htm).

4. The figure includes commercial films, TV shows, documentaries, and other video. ANDERSON, supra note 2, at 26; but see Eldred v. Ashcroft, 537 U.S. 186, 253 (2003) (Breyer, J., dissenting) (citing AnNetTe Melville \& ScotT Simmon, Library of Cong., Film PRESERVATION 23 (1993)) (suggesting that public archives hold roughly 200,000 film and video titles).

5. See Rob Bamberger \& SAM Brylawski, Library of CONG., THE State of RECORDED SOUND PRESERVATION IN THE UNITED STATES 47 (2010), available at http://www.clir.org/pubs/reports/publ48/publ48.pdf. At least twenty million titles are currently available for downloading over the Internet. See John Jurgensen, An Ode to Joyful Music Streaming, WALL ST. J., Jan. 3, 2014, http://online.wsj.com/news/articles/SB100014240527023045916 04579290721300786680 .

6. Robert Darnton, The National Public Digital Public Library is Launched!, N.Y. REV. BoOKS, Apr. 25 2013, available at http://www.nybooks.com/articles/archives/2013/apr/25/nationaldigital-public-library-launched. The figure includes duplicates.

7. One way to test completeness is to compare Google's collections against bibliographies compiled by enthusiasts. The author checked 100 randomly-selected "Cowboys and Indians" titles from the exhaustive bibliography found in Encyclopedia of Western Lawmen and Outlaws. JAY ROBERT NASH, ENCYCLOPEDIA OF WESTERN LAWMEN AND OUTLAWS (1994). Remarkably, all were available on Google. The test is especially stringent since Western books have small print runs, are poorly represented in university libraries, and have typically been out-of-print for decades.

8. Robert Darnton, Op.-Ed., A Digital Library Better Than Google's, N.Y. TIMES, Mar. 24, 2011, at A31 (describing digitization initiatives in France, the Netherlands, Japan, Australia, Norway, and Finland.).

9. See, e.g., YEARBOOK COMM. \& ASSOCIATED CONTRIBUTORS, NAT'L SOC'Y FOR THE STUDY OF EDUC., MICROCOMPUTERS AND EDUCATION 24 (Jack A. Culbertson et. al., eds., 1986) (arguing that technological innovation allows students to obtain "instant electronic access to the entire sum of human knowledge.").

10. Raymond Chandler, The Simple Art of Murder, ATLANTIC MONTHLY, Dec. 1944, at 53, 53. Or maybe Hemingway did not say it since Chandler admits that he supplied the quotation from memory. Wording aside, Hemingway undoubtedly expressed similar sentiments on other occasions. Cf. ARNOLd SAMUELSON, WITH HEMINGWAY 12 (1984) ("Compete with the dead ones you know are good. Then when you can pass them up you know you're going good."). 
This could soon be the literal truth. ${ }^{11}$

Much of this work is valuable, and even extraordinary. As the Roman satirist Martial knew, many deserving authors go unnoticed or are initially derided. $^{12}$ For example, Percy Bysshe Shelley, ${ }^{13}$ Henry James, ${ }^{14}$ and Herman Melville ${ }^{15}$ were all overlooked for decades before being discovered. ${ }^{16}$ The same is also true for movies and music. ${ }^{17}$ There are also contemporary examples. Many people think that J.K. Rowling is a genius; however, her book The Cuckoo's Calling, written under a pseudonym, sold just five hundred copies before she relented and allowed the publisher to use her real name. ${ }^{18}$

11. Cf. Hannah Karp, Old College Try: No-Hit Wonders Get a Fresh Shot at Fame, WALL ST. J., Sept. 21, 2013, http://online.wsj.com/news/articles/SB 10001424127887323 864604579070122905147530 (arguing that college bands that were waiting to be discovered in the 1980 s may yet get their chance).

12. For example, Martial ridicules a young provincial who hopes to make a living by writing verses as good "as Virgil's own": "You are mad; all that you see here shivering in threadbare cloaks are Ovids and Virgils. [You say] 'I will push my way among the great.' That trick has found support for but two or three that have attempted it, while all the rest are pale with hunger." Martial, epigrammata 3.38. See also, George Haven PuTnam, Authors AND THEIR Public IN ANCIENT TIMES 250 (Cooper Square Publishers, 3rd ed. rev. 1966) (1893) ("[M]atrial refers more than once to many amiable and deserving authors who, despite their talents, succeeded in reaching no public at all...").

13. SYLVIAN NORMAN, Flight of the Skylark: The Development of Shelley's Reputation

14. Joseph Epstein, The Afterlife of the Lion, WALL ST. J., Jan. 14, 2012, http://online.wsj.com/news/articles/SB10001424052970204257504577150881748541906 (James' reputation was restored in 1943 after twenty years of being "out of print, out of readers and out of luck.").

15. Melville's Moby Dick (1851) sold poorly during the author's lifetime but acquired a cult following in the 1890s. This was followed by a critical revival in the 1920s. Melville's current lofty reputation only emerged in the 1940s. Chris Gaylord, Herman Melville Books: At First, 'Moby Dick' Was a Total Flop, CHRISTIAN SCI. MONITOR, Oct. 18, 2012, http://www.csmonitor.com/Innovation/Tech-Culture/2012/1018/Herman-Melville-books-At-firstMoby-Dick-was-a-total-flop.

16. The opposite is also true: many authors lionized in their own time eventually drop from sight. Writing in the 1930s, George Orwell expressed surprise at how many Edwardian bestsellers have been forgotten: "How many of the names in that list are known to you, I wonder? Half the books that people took seriously in those days are forgotten now." GEORGE ORWELL, COMING UP FOR AIR 125 (Peter Davison ed., Secker \& Warburg 1997) (1939).

17. See Duncan J. Watts, A Simple Model of Global Cascadess on Random Networks, 99 PROC. NAT'L ACAD SCI. 5766, 5766 (2002) ("Why do some books, movies, and albums emerge out of obscurity, and with small marketing budgets, to become popular hits ... when many a priori indistinguishable efforts fail to rise above the noise?"); see also David Thomson, When is a Movie Great? The Perils of Medium and Magic, HARPER'S, Jul. 2011 at 35, 36 (arguing that "every year some extraordinary film is missed"); Karp, supra note 11 (members of the music industry believe that " " $t]$ here are thousands of songs out there that could have been hits." ).

18. Paul Elie, Bound to Please, WALL ST. J., Aug. 3, 2013, http://online.wsj.com/news/articles/SB10001424127887324110404578625801325451188. Orwell recounts a similar experiment in which people were asked to rate obscure works by well-known poets. His typically acerbic conclusion was that "many people who would describe themselves as lovers of poetry have no more notion of distinguishing between a good poem and a bad one than a 
These examples point to a more general lesson: word-of-mouth networks cannot be trusted to find the best titles. ${ }^{19}$ Readers have always sought out recommendations from friends ${ }^{20}$ and scholars have spent the past decade writing simple computer models to study how this advice percolates through networks. ${ }^{2 T}$ Despite their simplicity, the models make generic predictions that fit sales data remarkably well. ${ }^{22}$

Probably the most important prediction involves growth. The extreme cases are fairly predictable-if the initial number of readers is small, new books have almost no chance of propagating. ${ }^{23}$ Conversely, books that start out with large numbers of readers quickly become universal. ${ }^{24}$ However, the middle ground is more surprising. Here, outcomes are uncertain: everything depends on which readers are randomly selected to "seed" the chain. ${ }^{25}$ For most seeds, sales stay small and limited. ${ }^{26}$ But a few otherwise unremarkable seeds trigger avalanches that cascade across the network. ${ }^{27}$ The lesson is that small differences in how books are launched have large consequences. ${ }^{28}$ Two thousand years later, we

dog has of arithmetic." George Orwell, As I Please, TRIBUNE (London), May 5, 1944, available at http://telelib.com/authors/O/OrwellGeorge/essay/tribune/AsIPlease19440505.html.

19. See Edward Nawotka, What's the Key to Solving the Book Discoverability Problem?, Publishing PERSPECTIVES (Nov. 18, 2013), http://publishingperspectives.com/2013/11/whats-thekey-to-solving-the-book-discoverability-problem/.

20. Bodo Lang \& Rob Lawson, Dissecting Word-of-Mouth's Effectiveness and How to Use It as a Proconsumer Tool, 25 J. NONPROFIT \& PUB. SECTOR MKTG. 374, 375 (2013).

21. See, e.g., F. Deschatres \& D. Sornette, Dynamics of Book Sales: Endogenous Versus Exogenous Shocks in Complex Networks, 72 PHYSICAL REV. 016112, 016112-1 to -2 (2005) (citing D. Sornette et al., Endogenous Versus Exogenous Shocks in Complex Networks: An Empirical Test Using Book Sale Rankings, 93 PHYSICAL REV. LETTER 228701, 228701-4 (2004); B.M. Roehner et al., Response Functions to Critical Shocks in Social Sciences: An Empirical and Numerical Study, 15 INT'L J. MOD. PHYSICS C 809 (2004)). For a comprehensive review of epidemiological models and network theory, see generally Mark E. J. Newman, The Structure and Function of Complex Networks, 45 SIAM REV. 167 (2003) (reviewing recent empirical studies of networked systems). In practice, most simulations rely on a handful of simple parameters including (a) rules for deciding when recommendations are persuasive, (b) the size of the network, (c) the "lag" between the time people start reading and when they communicate recommendations to others, (d) the average size of networks, (e) the size distribution of highly connected sub-networks, and sometimes (f) the presence of unusually persuasive "influentials" and/or unusually persuadable "susceptibles" in society. See Duncan J. Watts \& Peter Sherman Dodds, Influentials, Networks, and Public Opinion Formation, 34 J. CONSUMER RES. 441, 442-43 (2007) (describing computer model of influence networks). These are poorly known in practice See id. at 443 (citations omitted).

22. See, e.g., Deschatres \& Sornette, supra note 21, at 016112-1 (arguing that Amazon sales rankings grow according to predicted power law).

23. See id. at 445 .

24. See Deschatres \& Sornette, supra note 21 , at 016112-1.

25. See, e.g., Watts, supra note 17 , at 5767-68 (modeling how consumer interactions influence final sales outcomes).

26. Id.

27. See id. at 5766; Deschatres \& Sornette, supra note 21, at 016112-8; Watts \& Dodds, supra note 17 , at 445 (citing Watts, supra note 17 , at 5769 ).

28. See Deschatres \& Sornette, supra note 21 , at 016112-15. 
finally understand Martial's complaint that chance rewards some authors more than others. ${ }^{29}$

\section{B. Beyond Computer Models}

Computer models are surprisingly lifelike and even explain the role that chance plays in deciding which new books reach consumers. ${ }^{30}$ At the same time, they ignore the obvious fact that some works are better than others. This may not matter much for the first few generations of consumers who must decide based on minimal information - a sixty second advertisement, say, or a few lines sampled in a bookstore. But computer models cannot possibly be right once the work has sold so many copies that consumers can get recommendations from friends. At this point, we expect word of mouth networks to recommend good works much more often than the computer models predict. The importance of this effect varies by industry. For example, book titles can take years to reach bestseller status. ${ }^{31}$ This gives word of mouth ample time to correct first impressions. Conversely, Hollywood deliberately suppresses word of mouth by releasing new movies onto as many screens as possible. ${ }^{32}$ This helps bad films do better in the first week while increasing the number of people who can give word of mouth advice thereafter. Both factors accelerate the rate at which the market embraces or rejects new films. ${ }^{33}$

Computer models also ignore production costs. For example, two-fifths (39.2 percent) of all Amazon book sales involve titles ranked at 100,000 or higher. ${ }^{34}$ Prior to the Digital Age, scale economies ensured that many specialized titles had too little demand to be profitable ${ }^{35}$ although this constraint slowly relaxed as technical and social innovations increased the number of

29. See supra note 12 and accompanying text.

30. See supra Part III.B.

31. See, e.g., Deschatres \& Sornette, supra note 21, at 016112-15 (quoting MALCOLM Gladwell, The TIPPING POINT 169-70, 174 (2002)) (explaining how Divine Secrets of the Ya-Ya Sisterhood took almost two years to reach bestseller status).

32. The modern tactic was pioneered in the 1970s when Jaws opened on an unprecedented 400 screens. Today's movies commonly open on 3,000 screens. Thomson, supra note 17, at 37 . Similar business strategies date back to the 18 th Century when publishers routinely launched advertising. campaigns weeks before the publication date. See SHER, supra note 1, at 361-62.

33. See, e.g., All Time Box Office, Box OffICE MOJo (last updated Sept. 1, 2014, 9:08 PM), http://boxofficemojo.com/alltime/weekends/ (box office receipts fall steeply for bad movies after the first week but continue to grow for classics).

34. Erik Brynjolfsson et al., Consumer Surplus in the Digital Economy: Estimating the Value of Increased Product Variety at Online Booksellers, 49 MGMT. SCI. 1580, 1588-89 (2003), available at http://papers.ssm.com/sol3/papers.cfm?abstract_id=400940.

35. See ANDERSON, supra note 2, at 16-18. 
readers. ${ }^{36}$ This trend has reached its limit in the Digital Age where economies of scale are so small that selling even a few copies becomes profitable. ${ }^{37}$

Finally, computer models assume that consumers are passive and cannot find works for themselves. This has never been entirely true, as anyone who has rummaged through a used bookstore knows. Online book, music, and video archives have made the task even easier. ${ }^{38}$ Despite this, individual search remains marginal. One reason for this is that it is uncoordinated. This means that there is no way to warn others about disappointing titles so that searchers end up reading the same bad books over and over again. Individual search incentives are also fragile. Naively, one expects readers to stop searching as soon as someone suggests better titles than they can find for themselves. ${ }^{39}$ This means that government-and commercially-funded searches can crowd out private effort. ${ }^{40}$ We return to this problem in Part VII.C.

\section{Doing Better: The Role of Institutions}

Word of mouth networks elevate some works at random while overlooking others. This implies that consumers should be willing to pay a premium to support institutions that help the market find better titles. The practical problem is that humans are extraordinarily bad at guessing what other humans like. ${ }^{41}$ There are basically two ways to get around this difficulty.

36. Historic examples include technologies for making cheaper books, continent-wide distribution networks, and shared purchases through libraries. See infra Part IV.

37. For an extended version of this argument, see generally ANDERSON, supra note 2, at 16 (arguing that the Digital Age has allowed niche items to find a market where only 'blockbusters' could survive in the past).

38. See id. at 22-24.

39. Individual search is more resilient where each consumer has slightly different preferences. Cf. Joachim Henkel, The Jukebox Mode of Innovation - A Model of Commercial Open Source Development 2-4 (Ctr. Econ. Pol'y Res., Discussion Paper No. 4507, 2004), available at http://papers.ssrn.com/sol3/papers.cfm?abstract_id $=578142$ (analyzing open source model where each collaboration member concentrates on whichever project most appeals to her).

40. The principle also applies to non-commercial search collaborations: The more members share good titles, the less incentive they have to try new ones.

41. This makes copyright fundamentally different from patents, whose quality can usually be reduced to a single numerical parameter like "cost savings." See generally John F.R. Harter, The Propensity to Patent with Differentiated Products, 61 S. ECON. J. 195, 200 (1994) (arguing that decision to patent is determined by the invention's performance and cost advantages). The Family Feud game show, in which contestants are asked to predict how studio audiences will answer a specific question, presents the phenomenon in miniature. The aesthetic value of NASA images is similarly unpredictable. See Lucy Cramer, Hubble Madness: Space Odyssey Heads to Final Round, WALL ST. J., Apr. 7 2014, http://online.wsj.com/news/articles/ SB20001424052702303532704579482021707961280 (quoting 2014 Hubble Madness: Round I Recap, NASA (Mar. 28, 2014), https://www.facebook.com/notes/hubble-space-telescope/2014hubble-madness-round-1-recap/721724074525279). 
The most familiar response is to hire experts variously called "editors," "producers," and "entertainment executives" to find and publicize new titles. The problem is that expert judgment is remarkably fallible: In screenwriter William Goldman's famous phrase, "[n]obody knows anything."43 While Goldman probably overstated his case, ${ }^{44}$ the basic point is evident from the enormous number of Hollywood bombs and flops ${ }^{45}$ that sometimes drive major studios to the edge of bankruptcy. ${ }^{46}$ Similar points can be made for books ${ }^{47}$ and music. $^{48}$

But if nobody knows anything, how should publishers decide? The traditional solution has been for editors and authors fall back on personal taste. As J.R.R. Tolkien explains:

As a guide I had only my own feelings for what is appealing or moving, and for many the guide was inevitably often at fault. Some who have read the book, or at any rate have reviewed it, have found it boring,

42. See, e.g., William Goldman, AdVEnTURES IN THE SCREEN TRADE 39 (1983) (describing the role of studio executives in the film industry).

43. Id. ("Not one person in the entire motion picture field knows for a certainty what's going to work. Every time out it's a guess-and, if you're lucky, an educated one."). Producer David O. Selznick felt similar doubts about his masterpiece Gone with the Wind. When asked how he felt about the film, he replied "At noon I think it's divine, at midnight I think it's lousy. Sometimes I think it's the greatest picture ever made. But if it's only a great picture, I'll still be satisfied." Cinema: $G$ with the $W$, TIME, Dec. 25, 1939, available at http:/content.time.com/time/magazine/article/0,9171,762137,00.html/.

44. As Clifton Fadiman remarked, the average critic "wouldn't hold his job long" unless his estimates were "appreciably more reliable than those of your dinner-table companion." Clifton Fadiman, The Reviewing Business, HARPER's, Oct. 1941, at 472, 476. More careful studies show that the prices that studios pay for scripts have a "positive and significant" correlation to eventual box office revenues. William Goetzmann et al., The Pricing of Soft and Hard Information: Economic Lessons from Screenplay Sales, 37 J. CULTURAL ECON. 271, 297 (2013).

45. See generally Greatest Box-Office Bombs, Disasters and Flops, FILMSITE, http://www.filmsite.org/greatestflops.html (last visited Nov. 8, 2014) (providing an inflation adjusted list of money-losing films); MICHAEL MEDVED \& HARRY MEDVED, THE HOLLYWOOD HALL OF SHAME (1984) (providing a history of movie industry flops).

46. Noteworthy catastrophes include Waterworld, Heaven's Gate, and Cleopatra. Bernard Weinraub, 'Waterworld' Disappointment as Box Office Receipts Lag, N.Y. TIMES (Jul. 31, 1995), http://www.nytimes.com/1995/07/31/business/waterworld-disappointment-as-box-office-receiptslag.html; Robert W. Welkos, The Film Flop That Reshaped Hollywood, L.A. TIMES (Jun. 12, 2004), http://articles.latimes.com/print/2004/jun/12/entertainment/et-welkos12; John Patterson, Cleopatra, the Film That Killed Off Big-Budget Epics, GUARDIAN (UK) (Jul. 12, 2013), http://www.theguardian.com/film/2013/jul/15/cleopatra-killed-big-budget-epics/.

47. See Boris Kachka, The End, N.Y. MAG. (Sept. 14, 2008), http://nymag.com/news/media/50279/ ("One British publisher advised an American ... 'Take lots and lots of gambles, but small ones."'); ERNEST HEMINGWAY, THE GARDEN OF EDEN 23 (Scribner's Sons 1986) ("His publisher wished he could say more about how the book would do but he never made predictions as to sales. It was bad practice.").

48. Only one in ten recordings earns a profit. Robert Lee Hotz, Songs Stick in Teens' Heads, WALL ST. J. (June 14, 2011), http://online.wsj.com/news/articles/SB10001424 052702303848104576381823644333598 . 
absurd, or contemptible; and I have no cause to complain, since I have similar opinions of their works, or of the kinds of writing that they evidently prefer. ${ }^{49}$

The alternative is to dispense with human experts and collect or infer human judgments directly from audience members. ${ }^{50}$ Society has experimented with variations on this strategy since Homer's time. Modern search engines are the latest incarnation of this approach. ${ }^{51}$ Finally, effective institutions need to do more than simply predict popular titles; they must also persuade the public to read them. In practice, this means delivering enough initial seed readers to overcome the vagaries of Martial's network. ${ }^{52}$ This can almost always be done through marketing tactics like advertising or giving away free copies. ${ }^{53}$ At the same time, commercial publishers have an obvious incentive to "hype" their own titles. This forces the public to discount all publisher recommendations including the honest ones. ${ }^{54}$

\section{The First AgE of SEARCH: A World Without Printing}

The earliest literature was based on direct interactions between authors and audiences. ${ }^{55}$ The introduction of commercial publishing in the first century A.D.

49. J.R.R. TOLKIEN, THE FELlowSHIP OF THE RING 6 (2d ed. 1965). See also Elie, supra note 18 ("This is literary publishing, and it's a business where your best guess about what might attract readers to give of their time is simply what you yourself are willing to spend time with."). Raymond Chandler held similar views:

I have never had any great respect for the ability of editors, publishers, play and picture producers to guess what the public will like. The record is all against them. I have always tried to put myself in the shoes of the ultimate consumer, the reader, and ignore the middleman. I have assumed that there exists in the country a fairly large group of intelligent people ... who like what I like.

Letter from Raymond Chandler to George Harmon Coxe (Jun. 27, 1940) in SELECTED LETTERS OF RAYMOND CHANDLER 17 (Frank MacShane ed., Columbia Univ. Press 1981).

50. See, e.g., David L. Morgan, Focus Groups, 22 ANN. REV. SoC. 129, 133-34 (1996) (discussing the uses of focus groups and surveys).

51. See infra Part IV.A.

52. See Watts \& Dodds, supra note 17 , at 443.

53. See supra note 13 and accompanying text. As Disney executive Alan Horn notes, "[Y]ou can buy an opening weekend.... It will be disappointing for you and for them, but you can get them in those seats." ANITA ElbERSE, BLOCKBUSTERS: HITMAKING, RISK-TAKING, AND THE BIG BUSINESS OF ENTERTAINMENT 69 (2013) (internal quotation marks omitted).

54. The problem is smaller when consumers expect to buy multiple books over time. In this case, honest publishers are more likely to sell books in the future. See SHER, supra note 1, at 7 (18th century consumers arguably looked to publishers' reputations for quality as much as authors'). Unfortunately, the mechanism also guarantees higher book prices and smaller readerships. See Carl Shapiro, Premiums for High Quality Products as Returns to Reputations, 98 Q. J. ECON. 659, 65960 (1983).

55. See infra Part IV.A. 
let ancient society find, manufacture, distribute, and market books on a much larger scale. ${ }^{56}$ At the same time, the model was only sustainable so long as publishers could charge markups above the physical cost of copies. ${ }^{57}$ This meant inventing tough-minded self-help strategies to deter would-be copyists. ${ }^{58}$ Even so, the system did almost nothing to protect titles after the first edition. ${ }^{59} \mathrm{We}$ argue that this apparently minor oversight forced ancient publishers to systematically ignore new authors in favor of "classics" written centuries before. $^{60}$

\section{A. Prehistory}

The first literature was oral. ${ }^{61}$ Homer probably composed the Iliad and Odyssey in the eighth century B.C. ${ }^{62}$ However, neither epic was written down for two hundred years. ${ }^{63}$ By then, the texts had been refined thousands of times by bards and audiences. ${ }^{64}$ This anticipated the modern open source mantra that "'given enough eyeballs, all bugs are shallow.", 65

Remarkably, none of this required copyright. Instead, storytellers who invented improvements recovered their costs by telling better stories and earning more money from each performance. ${ }^{66}$ Though much reduced, this link between

56. See infra Part IV.C.

57. See infra Part IV.C-D.

58. See infra Part IV.C.

59. See infra Part IV.C-D.

60. See infra Part IV.D.

61. See, e.g., John Chadwick, The Descent of the Greek Epic, 110 J. HELLENIC STUD., 174, 174 (1990) ("It is now generally accepted that down to the time of and including Homer himself the Greek epic tradition was oral ....").

62. Id. (citing P. Kyle MCCARTER, The ANTIQUity OF THE GREeK AlPHABET AND THE EARLY PHOENICIAN SCRIPTS 118 (1975)).

63. See id.

64. See John Miles Foley, "Reading" Homer Through Oral Tradition, 34 C. LITERATURE 1, 1-2 (2007). Professor Bettleheim argues that this incessant polishing gives folklore its enduring relevance and power. See generally BRUNO BETTLEHEIM, THE USES OF ENCHANTMENT: THE MEANING AND IMPORTANCE OF FAIRY TALES 12-19 (1976) (discussing how audience taste and experiences shaped fairytales).

65. ERIC S. RAYMOND, THE CATHEDRAL AND THE BAZAAR: MUSINGS ON LINUX AND OPEN SOURCE BY AN ACCIDENTAL REVOLUTIONARY 30 (2001).

66. Crucially, the average bard was both a consumer and a producer of improvements. This meant that the bard's net benefit was usually close to zero. $C f$. Suzanne Scotchmer, Openness, Open Source, and the Veil of Ignorance, 100 AM. ECON. REV. 165, 165 (2010) (explaining how innovators join open-source collaborations based on a net judgment that "improvements or cost reductions provided by a rival's open-source contributions ... outweigh the deleterious effect of empowering the rival to be a better competitor"). Modern examples of oral traditions that polish shared works over decades include American "blues" and "Mor Lam" music in Thailand. See, e.g., James Hookway, In Thailand, Copyright Enforcement Comes As a Shock, WALl ST. J., Mar. 31 2014, http://online.wsj.com/news/articles/SB10001424052702304250204579433493214015678. 
authors and audiences has continued down to the present. $^{67}$

On the other hand, the bards' incremental improvements took centuries to accumulate. ${ }^{68}$ This was never going to be good enough for authors who wanted to publish in their own lifetimes. Commercial institutions eventually emerged to fill the gap.

\section{B. Origins of Written Culture}

Books were published in Greece as early as the seventh century B.C. ${ }^{69}$ At first, the number of physically obtainable titles was so small-some books were published as a single reference copy ${ }^{70}$ - that readers had no difficulty choosing what to read. However, readers found it much harder to cope once the number of titles grew beyond one thousand or so. ${ }^{71}$ Greek society probably reached this point when the organized book trade and private libraries appeared early in the fifth century B.C. ${ }^{12}$ By the third century B.C., the Great Library of Alexandria had collected most of Greek literature ${ }^{73}$-the equivalent of perhaps 20,000 modern paperbacks ${ }^{74}$-in a single location.

67. See, e.g., William JOHNSON, READERS AND READING CULTURE IN THE High ROMAN EMPIRE 42-56 (2010) (discussing audience/author interactions in Roman times); SHER, supra note 1 , at 107-08 (describing how 18th $\mathrm{C}$. learned societies and café circles polished drafts); ANDREW LYCETT, IAN FLEMING: THE MAN BEHIND JAMES BOND 298-99 (1995) (describing how lan Fleming changed James Bond's pistol after a fan complained of 007 's "rather deplorable taste in firearms." ").

68. See M.L. West, The Rise of the Greek Epic, 108 J. HELLENIC STUD., 151, 151 (1988).

69. See M.L. West, Grated Cheese Fit for Heroes, 118 J. HELLENIC STUD., 190, 190 (1998).

70. L.D. REYNOLDS \& N.G. WILSON, SCRIBES AND SCHOLARS: A GUIDE TO TRANSMISSION OF GREEK AND LATIN LITERATURE 1 (3rd ed. 1991).

71. It takes modern readers roughly five hours to read the average book. Impressive and Amusing Facts, TREDITION CLASSICS (Sept. 2, 2012), http://web.archive.org/web/ 20120920002406/http://www.tredition.com/odd-facts (accessed by searching for Tredition in the Internet Archive Index). Assuming eight-hour days without vacations, this comes to about 30,000 volumes over fifty years. A better estimate would allow. for the fact that most real readers have day jobs, but can also skim or discard many texts immediately. No matter how the arithmetic is done, it is hard to see how the average human can perform reasonable searches once the number of titles passes 10,000 or so. That said, one scholar claimed to have read every Greek text in existence as late as the second century B.C. LIONEL CASSON, LIBRARIES IN THE ANCIENT WORLD 38 (2001).

72. REYNOLDS \& WILSON, supra note 70, at 2, 5 (citing Eupolis, The Fragments in Translation, reprinted in IAN STOREY, EUPOLIS, POET OF OLD COMPANY 27 (2003); Plato, Apology, in Five Great Dialogues 44 (Louise Ropes Loomis ed., B. Jowett trans., 1942)).

73. The Great Library tried to collect every Greek text ever written. CASSON, supra note 71, at 35-36 ("The policy was to acquire everything, from exalted to epic poetry to humdrum cookbooks"); REYNOLDS \& WILSON, supra note 70, at 7 ("great efforts were made to form a complete collection of Greek literature").

74. The Library possessed an estimated 490,000 rolls with another 42,800 in a satellite facility. CASSON, supra note 71, at 36. Howard and Avrin argue for a somewhat higher figure of 700,000 scrolls. NiCOLE HOWARD, THE BOOK: THE LifE STORY OF A TECHNOLOGY 20 (2005). See generally LEILA AVRIN, SCRIBES, SCRIPT AND BOOKS: THE BOOK ARTS FROM ANTIQUITY TO THE 
Commercial scribes copied these texts for clients across the Empire. ${ }^{75}$

Readers could now obtain any title they wanted. The problem was knowing what to ask for. For the most part, searches were performed by noncommercial literary circles whose members identified, advised, and publicized deserving authors. $^{76}$ This continued the Homeric pattern of letting audiences improve titles. Like modern samizdat, circle members also manufactured most of their own books. ${ }^{77}$ Whatever its defects, the method was wonderfully sincere. ${ }^{78}$ The bare fact that a book existed showed that someone, somewhere, had thought it worth copying. ${ }^{79}$

\section{The First Commercial Publishers.}

Samizdat-style production relied on amateurs to make one-off copies. Such methods could not possibly support specialization or economies of scale. Roman society responded by organizing commercial publishing firms that used high markups to pay employees. But for the new business model to work, publishers had to find a way to suppress copyists. In practice, we argue that the Romans were never able to protect books beyond the first edition. This crippled search and reinforced the ancient world's notorious preference for long-dead authors.

The first unmistakable references to commercial book manufacturing date from the first century A.D. ${ }^{80}$ Scholars have argued about the industry's size for

RENAISSANCE 153 (1991) ("[T]he library of Alexandria ... was said to have housed seven hundred thousand volumes. Even if one book filled four or five rolls . . or if Alexandrians exaggerated their library's size, it was still a large collection.").

75. HOWARD, supra note 74 , at 20 . Availability improved further in the 2 d Century as new libraries brought physical copies closer to readers. The Pergamum in Asia Minor possessed at least 200,000 works. CASSON, supra note 71, at 48-52; HOWARD, supra note 74, at 20 . Fragmentary evidence suggests that many cities built smaller libraries that offered standard works. See generally CASSON, supra note 71, at 57-58 (summarizing archeological evidence for donor-supported libraries).

76. JoHNSON, supra note 67, at 42-56. See also Katharina de la Durantaye, The Origins of the Protections of Literary Authorship in Ancient Rome, 25 B.U. INT'L. L. REV. 37, 45, 59 (2007); MARTIAL, EPIGRAMMATICA 6.1 in MARTIAL'S EPIGRAMS 101 (Gary Wills trans., 2008); PLINY THE YOUNGER, EPISTULARUM LIBRI DECEM 1.2.1; 1.8 .3 (R.A.B. Mynors ed. 1963); STATIUS: SILVAE, 2. Prooem. 29) (describing how ancient literary circles distributed drafts for comment and publicized promising authors).

77. See, e.g., CASSON, supra note 71 , at 77 (suggesting that in the age of private libraries, most book acquisitions were made by borrowing the text and then having a copy made before returning it).

78. See id. at 77 .

79. The inference is qualified by the use of slaves, which allowed the owner to make copies without actually reading the book. $I d$. at 77-78.

80. Cf. Jon W. Iddeng, Publica aut peri! The Releasing and Distribution of Roman Books, 81 SYMBOLAE OSLOENSES: NOR. J. GREEK \& LATIN STUD. 58, 64 (2006) ("From the late republican times of Cicero... on to the times of Martial and Pliny at the turn of the first century there are numerous references to what has been considered publishing and editing"). See Durantaye, supra note 76 , at 47 (stating that a complex book trade is known to have existed by the end of the Republic); CASSON, THE ANCIENT LIBRARIES, supra note 71, at 27, 78 (stating that commercial 
more than a century. ${ }^{81}$ However, there can be no doubt that figures like Horace (d. 8 B.C.), Martial (d. 104 A.D.), and Quintillian (d. 100 A.D.) were celebrities whose works were sold throughout the Empire. ${ }^{82}$ Indeed, Pliny the Younger tells of "a rustic Spaniard who traveled to Rome just to catch a glimpse of Livy [d. 17 A.D.]." ${ }^{, 83}$ It is hard to imagine such fame without well-funded marketing and distribution programs. ${ }^{84}$ Publishers also performed modest search and marketing tasks, including paying authors for desirable manuscripts ${ }^{85}$ and handing out complimentary copies. $^{86}$ All of these tasks required a substantial commercial sector.

Commercial firms could also produce large book "runs" more cheaply than any amateur. ${ }^{87}$ Anyone who has copied text longhand knows how easy it is to

book manufacturing may have existed in 4th Century B.C. Greece and 1st Century B.C. Rome). See also George Haven Putnam, Books and their Makers During the MidDle Ages vii (2d ed. 1896) (arguing that the Augustan age copied and distributed literature "under an effective publishing and bookselling machinery, so as to reach an extensive and widely separated reading public.").

81. Scholars have debated whether commercial publishing was "fairly marginal or not" since the 19th Century. Iddeng, supra note 80, at 73. Most older scholarship argues that the industry resembled modern publishing. Scholars writing since the 1960 s usually stress that that the evidence is compatible with smaller enterprises. Professor Iddeng concludes that the truth lies in between but that non-commercial copying remained "the usual way of acquiring literature." Id. at 76. But see AVRIN, supra note 76, at 170 ("[F]or late republican and early imperial Rome, one can speak confidently of publishing as big business.").

82. See Iddeng, supra note 80 , at 68 (citing Seneca, de beneficiis 7.6; Martial, epigrammata $4.72,13.2)$.

83. Id. at 77 (citing Letter from Pliny the Younger, to Nepos, available at http://www.fordham.edu/halsall/ancient/pliny-letters.asp).

84. As Prof. Iddeng remarks, the Livy story "could only be told in a society where literature was distributed far more broadly than within a small erudite urban elite." Id. See also AVRIN, supra note 74, at 170 ("The vast amount of literary production in all parts of the Roman Empire ... implies an active profession of publishers and booksellers."); WILLIAM A. JOHNSON, BOOKROLLS AND SCRIBES IN OXYRHYNCHUS 158 (2004) (quoting HARRY Y. GAMBLE, BOOKS AND READERS IN THE EARLY CHURCH: A HISTORY OF EARLY CHRISTIAN TEXTS 88 (1995)) ("[A] bookseller would have found his best opportunities in a reading public that lay beyond aristocratic and scholarly literary circles and in provincial areas where books were otherwise hard to come by.").

85. Ancient sources contain various references to authors selling works to publishers. See Iddeng, supra note 80, at 73-75 (citations omitted); RICHARD ROGERS BOWKER, COPYRIGHT: ITS HISTORY AND ITS LAW 8 (1912). However, contemporary scholars are often skeptical. The main sticking point seems to be author complaints like Martial's joke that his "wallet doesn't notice." Idding, supra note 80, at 75 (citing Martial, epigrammata 2.3.6). This argument seems doubtful since modern authors say much the same thing. Even today, only one in every thousand authors who contact a literary agent ends up earning more than symbolic income. John Eggan, The Truth About Book Royalties (June 2, 2009), http://ezinearticles.com/?The-Truth-About-BookRoyalties\&id=2424907.

86. PUTNAM, supra note 12 , at 189 (stating that publishers maintained a "record of complimentary copies").

87. See, e.g., Iddeng, supra note 80 , at 75 (describing financial gain from using dictation to make multiple copies at once). For the modern literature on dictation, see JOHNSON, supra note 67 , at $39-41$. 
lose one's place. This made it faster and more efficient to hire readers so that scribes could write from dictation. ${ }^{88}$ The fact that many-but not all-ancient texts suffer from homonym errors shows that this method was widely used ${ }^{89}$ At the same time, dictation was inefficient for small production runs. In practice, ancient publishers probably produced twenty to fifty books at a time. ${ }^{90}$

Twenty copies may not seem like much. But even modern "superstores" seldom stock more than a dozen copies of any one title. In order to use dictation at all, then, book manufacturers would have had to build distribution markets across Rome or, better still, the entire Empire. ${ }^{91}$ Scholars have found considerable evidence that they did. ${ }^{92}$ The converse is also true. Dictation disappeared when Rome fell and only reappeared when medieval universities created a suitably large replacement market.

Roman jurists knew copyright as a "theoretical speculation" but never implemented it. ${ }^{94}$ This has led most scholars to assume that ancient publishers could not charge for content. ${ }^{95}$ However, classical references describe publishers

88. Id. at 67 (remarking that dictation is "obviously more efficient").

89. See PUTNAM, supra note 12 , at 120 . More recent scholars generalize the homonym insight by distinguishing between "visual" and "aural" errors buttressed by evidence from other primitive societies, theoretical arguments about the relative efficiency of dictation, oblique literary references, and pictorial evidence that Egyptian scribes sat in a cross-legged posture that made visual copying awkward. For the leading modern review, see THEODORE CRESSY SKEAT, THE USE OF DICTATION IN ANCIENT BOOK-PRODUCTION (1956), reprinted in THE COLLECTED BIBLICAL WRITINGS OF T.C. SKEAT 3-32 (J.K. Elliot ed., 2004); see also JOHNSON, supra note 67, at 21-22, 39-41. These necessarily inferential arguments make it hard to estimate the relative cost of producing texts by each method.

90. The lower limit was set by efficiency. Assuming, arguendo, that dictation makes each copyist ten percent more efficient, manufacturers would have to sell at least ten copies to cover the cost of hiring a read.er. The upper limit was set by the publisher's ability to supply scribes and working space. Medieval manuscript shops are known to have employed at least fifty scribes at a time. HOWARD, supra note 74, at 29.

91. This is still true today. Despite nationwide sales, most debut fiction only sells about 10,000 copies. Jeffrey A. Trachtenberg, The Future of the Book: Authors Feel Pinch in Age of EBooks, WALL ST. J. (Sept. 28, 2010), http://online.wsj.com/articles/ SB10001424052748703369704575461542987870022.

92. See PUTNAM, supra note 80 , at vii. Iddeng, supra note 80 , at 68,71 (citing Martial, eprigramatta 5.5., 7.17, 1.29, 1.38, 1.52, 1.53, 1.63, 1.66, 1.72, 2.6, 2.20, 11.94, 12.63; Quintillian, institutio oratia 1.pr.7) (arguing that Horace, Martial, and Quintillian enjoyed empire-wide sales).

93. See PUTNAM, supra note 80 , at 66 . Prof. Skeat argues that some early medieval manuscripts show evidence of dictation but that visual copying became the medieval norm. SKEAT, supra note 89 , at $24-27$.

94. See Durantaye, supra note 76 , at 38. PUTNAM, supra note 12 , at 268 (Roman jurists treated copyright as a "theoretical speculation" but passed no legislation to enact it). The Roman jurist Gaius (second century A.D.) argued that an artist who painted a picture on a tabletop possessed a superior right to the property. The opinion was later endorsed by Tribonian (d. 547). BOWKER, supra note 85 , at 8 .

95. More precisely, publishers could not recover fixed costs like paying royalties to the author, searching for lost texts, or editing corrupted passages. They could, however, have recovered variable costs like proof-reading or updating texts to include the author's latest revisions. Publishers with a reputation for quality could also have commanded an "efficiency wage" over and above their 
paying authors for manuscripts, ${ }^{96}$ granting booksellers the exclusive right to sell certain poems, ${ }^{97}$ and handing out complimentary copies to select readers. ${ }^{98}$ None of this would have been possible without at least some ability to deter copyists. $^{99}$

One explanation is that publishers with big distribution networks could achieve economies of scale that no local copyist could match. Theory suggests that they could have earned profits comparable to the resulting cost advantage over smaller competitors. ${ }^{100}$ This would have supported a very modest budget for marketing and search.

In fact, ancient publishers possessed a more powerful strategy. Ancient sources frequently mention publishers producing large numbers of unsold copies or, in today's jargon, "remainders." 01 This seems inexplicable-in a world without copyright, markups should have been so small that discarding just one or

editing costs. See Shapiro, supra note 42, at 659. The fact that the Roman publisher Atticus (d. 32 B.C.) became a byword for quality in an otherwise shoddy industry supports this theory. See, e.g., REYNOLDS \& WILSON, supra note 70, at 24 (stating that Atticus' "standards of execution were of the highest and his name a guarantee of quality.").

96. See supra note 61 and accompanying text.

97. BOWKER, supra note 85 , at 8 .

98. PUTNAM, supra note 12, at 189.

99. Traditional explanations are unsatisfactory. Some classics scholars have suggested that large book runs would have allowed manufacturers to charge a premium for "hot" titles. Iddeng, supra note 80 , at 75 . However, such premiums should have been miniscule in a world where copyists could quickly flood the market with copies. Other scholars have argued that publishers did not want to run the "dreadful risk of not having enough copies to meet the immediate demand." PUTNAM, supra note 12 , at 223. But this "risk" similarly makes no sense unless publishers could extract markups from future sales.

100. This is a familiar result in so-called Bertrand models of competition. See generally Bertrand Competition, WIKIPEDIA, http://en.wikipedia.org/wiki/Bertrand_competition (last visited Dec. 12, 2014) ("If one firm has lower average cost (a superior production technology) it will charge the highest price that is lower than the average cost and take all the business. This is known as "limit pricing."').

101. Scattered references to books being recycled as packing paper or fish-wrap might possibly be explained as literary taunts. For example, Catullus uses the fish wrap insult against his .literary rival Volusius. Durantaye, supra note 76, at 51 (citing Persius, satirae 1.41-43). Even so, the explanation is problematic. In order to be effective, an insult must be comprehensible. This suggests that the fish wrap outcome happened often enough for Catullus' audience to recognize the practice. Ancient writers also describe much larger numbers of books being burnt to heat public baths. PUTNAM, supra note 12, at 223 (citing GEORGE AUGUSTUS SimCOX, A History OF LATIN LITERATURE: FROM ENNIUS TO BOETHIUS 244 (1883)) ("[L]arge supplies of surplus stock found their way from the booksellers to the fires of the public baths."). Unsold books were also shipped to distant markets. Durantaye, supra note 76, at 51 . Modem publishers still dispose of their defective print runs this way. See Edition (book), WIKIPEDIA, http://en.wikipedia.org/wiki/Edition_(book) (last visited Dec. 12, 2014). Finally, publishers seem to have held some unsold titles for long periods. PUTNAM, supra note 12, at 188-89 (referring to publisher's unsold inventory of Ciceoro's Ligarian Oration). 
two copies would have been ruinous. ${ }^{102}$ According to this logic, no publisher should ever have produced a copy until the publisher was certain of selling it.

Far from being irrational, this Article argues that publishers used deliberately large inventories to deter copyists. To see how, begin with the special case where everyone knows that the public will buy exactly one hundred copies of a particular title. Suppose further that the publisher manufactures all one hundred copies immediately. Now imagine that a copyist creates the copyist's own unauthorized copy. At this point the copyist and the publisher will immediately realize (a) that someone will be stuck with an unsold copy, and (b) that it is far better to sell the extra copy at a loss than to receive no payment at all. These conditions guarantee that the unauthorized copy will lose money. Knowing this, the copyist will never produce the book at all.

In practice, of course, no publisher could predict sales so perfectly. Even so, the ability to markup prices would have given the publisher a cushion for unsold books. More than that, the publisher would have expected remainders. After all, the whole point of markups was to charge a monopoly price that would depress sales from one hundred to perhaps ninety-five copies. Far from losing money, publishers would have seen the five remaindered books as a kind of fee for suppressing copyists.

Did Roman merchants really understand the economics of this scheme? Classic "invisible hand" logic suggests that they did not have to. All that was required was for one or two copyists to go broke competing with a first edition. After that, merchants would know better.

\section{Was Ancient Search Efficient?}

This Article's deterrence argument suggests that publishers could protect content by producing large first edition inventories. This had several good features. First and most obviously, it generated enough surplus to support distribution and search. Second, a deterrent must be visible. This would have forced publishers to display their inventories and provided a powerful signal of quality. Unlike verbal assurances, readers could not dismiss this physical investment as hype. ${ }^{104}$ Finally, deterrence would have ended as soon as the first

102. The modest economies of scale available from dictation do not materially change this result. Assuming a "print run" of thirty books, the savings from a ten percent gain in each scribe's efficiency would be erased if just two books remained unsold.

103. Prof. Mark Schankerman (personal communication) points out that the argument is closely related to so-called "capacity deterrence" games in which the first firm to enter a new industry makes deliberately large investments in plant and equipment to deter later entrants. See, e.g., Jean Tirole, The Theory of Industrial Organization (MIT: 1989) at pp. 323-328.

104. A more careful analysis would include the circular case where publishers can increase sales by manufacturing more inventory. This would not change the basic point so long as book sales grew slowly enough for word-of-mouth networks to correct errors. See supra text accompanying notes $26-28$. 
edition ${ }^{105}$ sold out. This would have allowed more consumers to buy and enjoy literature.

On the other hand, self-help had an enormous downside. Modern publishers typically gamble on new titles knowing that only one in fifteen will succeed. ${ }^{106}$ However, this strategy only works when publishers can charge markups after the first edition sells out. Ancient publishers did not have this option. This would have forced them to focus on authors with predictable sales like Homer and other already-established writers. This conservatism was further reinforced by scale economies, ${ }^{107}$ government subsidies, ${ }^{108}$ and mandatory purchases for school use. ${ }^{109}$

This theoretical insight is testable. Observers have long argued that ancient literary taste was extraordinarily conservative. ${ }^{110}$ Modern archeology allows us to quantify these claims. Egypt's dry climate allows us to track the books in rubbish heaps and reconstruct bestseller lists from the first century B.C. through the seventh century A.D. ${ }^{111}$ Table 1 lists the bestselling authors from the second

105. This Article uses the term "first edition" to describe copies manufactured on or before the publication date. Modern publishers often expand the meaning to include copies ("impressions") produced after the book has already appeared. Definition of Term: First Edition, INTERNATIONAL LEAGUE OF ANTIQUARIAN BOOKSELLERS, https://www.ilab.org/eng/glossary/174-first_edition.html (last visited Nov. 9, 2014). I ignore this distinction in what follows.

106. Cf. Elie, supra note 18 (suggesting that publishing is a "winner-take-all game" in which 10 books out of 100 may be successful); Hotz, supra note 48 (stating that only one in ten songs earns a profit).

107. Because dictation was only profitable above some minimal scale, copies of Homer and the classics would have been cheaper than new titles.

108. See PUTNAM, supra note 12, at 248 (describing government financial support for literature).

109. See, e.g., CASSON, supra note 71, at 56 ("To be sure, one of the reasons for the many finds of [Homer and Euripides] is that both were used in the schoolroom, so a multitude of student copies must have existed"). The Church later expanded the canon by subsidizing the copying of selected Christian titles. George Haven Putnam, Books and Their Makers in the Middle Ages, supra at 77-78 (explaining how a sense of religious duty spurred medieval copyists to produce enormous numbers of church texts).

110. Id. at 262. Martial was acutely aware of the problem:

"For what reason shall I say it happens, that fame is refused to writers while living, and ... but few readers love the compositions of their own day .... Ennius was read by you, O Rome, while Virgil was alive; and Homer was derided by his own age. Barely did the theatres applaud and crown Menander; Ovid was known only to his Corinna.")

Martial epigrammata 5.10.

111. Lionel Casson, Libraries in the Ancient World (Yale 2001) 54-55; see generally, WILLIAM A. JOHNSON, BOOKROLLS AND SCRIBES IN OXYRHYNCHUS 158 (2004). Admittedly, archeological discoveries from garbage middens are not quite the same as New York Times bestseller lists. Proper modern comparisons need to focus on "all-time" bestseller lists that span decades or centuries. 
century. Remarkably, almost all of them had died four or five centuries earlier. Similar patterns can be found in Greek library records. ${ }^{112}$

Did commercial publishing cause this debacle? The alternative explanations are weak. Probably the most plausible is that fourth century writers were simply more talented than their successors. According to this theory, Homer's dominance is not very different from Shakespeare's. ${ }^{113}$ But this fails to explain the very different fate of second tier authors. According to the ancient pattern, American best seller lists should still be dominated by Marlowe and Lovelace. Instead, they reflect authors in every generation from Charles Dickens to Stephen King. ${ }^{114}$

The other possibility is that elites suppressed new authors. The fact that modern professors still end their Western Civilization courses in 1939 suggests that elites are indeed conservative. ${ }^{115}$ The real issue, however, is less whether ancient elites were conservative than whether they could impose their tastes on others. Today's scholars have done little to nothing to stop commercial publishing's rush to low quality, vulgar titles. ${ }^{116}$ Roman publishers could be similarly unscrupulous when there was money to be made. ${ }^{117}$ Why were the outcomes so different?

Finally, neither hypothesis explains why the Greeks' literary Golden Age only happened once. This is especially mysterious since similarly unique Golden Ages appear in Roman ${ }^{118}$

112: The same third and fourth century B.C. authors continued to dominate the Oxyrhynchus data until the Arab invasions at the end of the 7th century. Similar patterns can also be found in Greek library catalogs. One fragmentary list shows two-dozen titles by Euripides, a dozen by Sophocles (d. 405 B.C.), nearly a dozen by Diphilus (d. 291 B.C.), at least three by Menander (d. 290 B.C.), one by Demosthenes (d. 322 B.C.), and just one "obscure essayist." See CASSON, supra note 71 , at $58-59$.

113. Shakespeare (2-4 bn. copies) and Agatha Christie (2-4 bn. copies) are roughly four times as popular as the next nearest authors. See Best-Selling Authors of All Time, THE BEST-SELLING BoOKS, http://the-best-selling-books.com/the-best-selling-authors-of-all-time/ (last visited Nov. 9, 2014).

114. Shakespeare's nearest all-time competitors include Barbara Cartland (500-1 bn), Danielle Steele $(500-800 \mathrm{~m})$, Harold Robbins $(750 \mathrm{~m})$, Georges Simenon $(500-700 \mathrm{~m})$, Sidney Sheldon $(370-$ $600 \mathrm{~m}$ ), Enid Blyton $(300-600 \mathrm{~m})$, and Dr. Seuss $(100-500 \mathrm{~m})$. Non-twentieth century authors who probably sold more than one hundred million copies include Charles Dickens, Jane Austen, Alexandre Dumas (pere), Victor Hugo, and Jules Verne. The dominance of nineteenth and twentieth century authors clearly reflects the explosive growth of book manufacturing since 1800 . A more refined analysis would correct for this and make earlier authors more visible. See id.

115. Modern professors sometimes teach more recent authors like Toni Morrison on diversity grounds. Ancient elites made a similar exception for the Church fathers after the rise of Christianity. See generally PUTNAM, supra note 12, at 274-75 (describing growth of ecclesiastical literature and efforts to suppress pagan authors).

116. See Joe Queenan, Why Not the Worst?, N.Y. TIMES (May 6, 2007), http://www.nytimes.com/2007/05/06/books/review/Queenan.t.html.

117. AVRIN, supra note 74, at 171 ("Not all readers had their heads in the books of Virgil, Pliny, or Julius Caesar; Romans wrote and read grade B and X-rated books as well.").

118. Roman archeology offers no counterpart to the finds in Egypt. Id. at 162 (discussing scholars' "disappointment" with books recovered at Pompeii). Even so, it is worth noting that the 
and Chinese ${ }^{119}$ literature. By comparison, self-help methods provide a natural explanation. ${ }^{120}$ The first publishers needed something to sell. To the extent that the classics did not already exist they would have had to invent them. Once the shelves were full of titles, however, gambling on additional authors was no longer profitable. Instead, the same "golden codgers" 121 hung on for centuries. $^{122}$

\section{The Second Age of Search: Printing}

Commercial publishing collapsed after the Fall of Rome. ${ }^{123}$ For the next six hundred years, the monks who dominated book production concentrated on classics much as the Romans had. ${ }^{124}$ The turning point came when modern copyright statutes helped publishers recover profits beyond the first edition. ${ }^{125}$

\section{A. Medieval Publishing}

The final collapse of Rome's Empire in the early fifth century destroyed the market for all but the most popular titles. ${ }^{126}$ Commercial publishing disappeared $^{127}$ and book production was confined to monasteries. ${ }^{128}$ This empowered elite tastes and let a handful of classic titles dominate literature much as they had in ancient times. 129

most famous Roman authors overwhelmingly date from the late Republic and early Empire). Prof. Avrin, for example, lists a total of twenty-nine authors who died between the second century B.C. and the fourth century A.D. Of these, more than half (16) died between 43 B.C. (Cicero) and 127 A.D. (Juvenal). The pattern is even more pronounced if we consider that the last seven names are Church fathers writing for an entirely new audience. See id. at 163.

119. See PUTNAM, supra note 12, at 32-33 (referring to the "classical period" of Chinese writing).

120. One could argue that top authors interact with one another and improve each other's work. In that case, it might be easier to become "great" in some eras than others. But this is hardly a complete answer since the Elizabethan coterie of authors ( $\mathrm{ca} .1600$ ) was followed by the Romantics (ca. 1800) and the Modernists (ca. 1920). See generally 18 ENCYCLOPEDIA BRITANNICA 426-65 (15th ed. 2010) (describing the development of Enligsh Literature). This did not happen in ancient times.

121. W.B. Yeats, News for the Delphic Oracle, in The Collected PoEMS OF W.B. Yeats 337, 337 (Richard J. Finneran ed., 2d ed. 1996).

122. Change could still occur following the kind of dramatic external events that economists call "shocks." The rise of Christianity created entirely new audiences that had not existed before. This led to a new set of Church author incumbents who would also persist for centuries.

123. PUTNAM, supra note 80 , at viii.

124. See id. at ix.

125. See generally SHER, supra note 1, at 4 (arguing that the first modern copyright law, the Statute of Anne, accelerated the growth of publishing).

126. PUTNAM, supra note 80, at viii, 174.

127. Id.

128. Id. at 175 .

129. See id. at 174. 
Commercial bookmakers reemerged at the end of the twelfth century to serve the new universities. ${ }^{130}$ By the late Middle Ages, demand had recovered to the point where publishers reintroduced dictation. ${ }^{131}$ Together with falling labor and materials $\operatorname{costs}^{132}$ this reduced book prices so that the public demanded more titles. By the fifteenth century, commercial book producers had expanded beyond universities to serve the general public. ${ }^{133}$ Meanwhile, international book fairs ${ }^{134}$ restored the old Europe-wide market. ${ }^{135}$ Catalogs for the Frankfurt fair listed twenty thousand titles in the last third of the sixteenth century ${ }^{136}$ enough to fill the entire Library of Alexandria.

\section{B. Printing and After.}

The printing press was invented in $1450^{137}$ and had spread across Europe by $1465{ }^{138}$ The new technology offered spectacular economies of scale, and large print runs could cut unit costs by fifty percent. ${ }^{139}$ However, early runs averaged just two to three hundred copies and barely broke even. ${ }^{140}$ As in Roman times, profitability required large distribution networks. ${ }^{141}$ The turning point came in the 1480s when Dutch publishers began to sell church and other Latin language titles across Europe. ${ }^{142}$ Runs now averaged four to five hundred copies, with the largest publishers reaching approximately fifteen hundred. ${ }^{143}$ Thereafter, sales grew slowly; even eighteenth century runs seldom exceeded two thousand copies. ${ }^{144}$

130. See id. at 31 .

131. Id. at 66 (stating that dictation became the rule for publishers who produced large runs for universities).

132. See id. at 238, 291 (showing that book price also benefited from the introduction of paper in the 14th century and lower copyist wages after the fall of Constantinople in the 15th century).

133. See id. at $11,234$.

134. Id. at 287.

135. HOWARD, supra note 74 , at 76-77.

136. Id. at 77.

137. PUTNAM, supra note 80 , at ix.

138. HOWARD, supra note 74 , at 43 . By 1480 there were around fifty presses in Italy, thirty in Germany, five in Switzerland, nine in France, and four in England. FEBVRE \& MARTIN, supra note 136 , at $182,184-85$.

139. See FEBVRE \& MARTIN, supra note 136, at 110-11. The limit was set by the high cost of quality paper. See id. at 112-14; SHER, supra note 1, at 363 (stating that paper cost more than print and advertising combined). Low quality books would have been cheaper to make.

140. Gutenberg's original Bible probably totaled about 180 copies. HOWARD, supra note 74 , at 31. Handwritten copies remained cost-effective for small runs into the eighteenth century. Darnton, supra note 3.

141. Even the largest cities seldom purchased more than sixty copies of a particular title. See FEBVRE \& MARTIN, supra note 136, at 221. Many shipments contained fewer than a half dozen copies. See id.

142. See id. at 217-18.

143. Id. at 218.

144. SHER, supra note 1, at 86. 
Because of scale economies, the big publishers could sell books more cheaply than any local competitor. ${ }^{145}$ This priced copyists out of the market and let the big publishers pocket their cost advantage as profit. ${ }^{146}$ Would-be copyists fought back in two ways. First, they produced down-market substitutes like abridgments and low quality editions. ${ }^{147}$ This avoided ruinous head-to-head competition while peeling off readers who might otherwise have paid full price $^{148}$ Second, local printers lobbied their governments to exclude foreign competitors. ${ }^{149}$ Unsurprisingly, the new laws were bad for consumers. Lacking economies of scale, domestic books were often expensive and badly made. ${ }^{150}$

Legislation and piracy notwithstanding, the big Dutch publishers must have done a good job of suppressing copyists since they often earned two to three times their production costs. ${ }^{159}$ Publishers used this revenue to recoup the massive costs of locating and correcting ancient manuscripts ${ }^{152}$ and to pay royalties that made top authors "substantially independent.".153

The Dutch publishing empire dominated Europe for nearly two hundred years. ${ }^{154}$ However, it depended on being able to sell the same Latin-language

145. The big publishers also had to suppress competition among themselves. This was relatively easy in an era when cartel agreements could be enforced in court. BOWKER, supra note 85 , at 10-11 (describing fifteenth century German cartel agreements); SHER, supra note 1, at 26 (describing how London's elite publishers used "mutual compacts" to enforce extralegal "honorary copyright" in the eighteenth century); Isabella Alexander, All Change for the Digital Economy: Copyright and Business Models in the Early Eighteenth Century, 25 BERKELEY TECH. L.J. 1351, 1357-58 (2010) (describing London publishers' use of "conger" agreements to cartelize sales).

146. In theory, publishers could also have extended their monopoly past the first edition by storing and re-using their typeset frames. In practice, this was hardly ever done. JAN LUTEN VAN ZANDEN, TECHNOLOGY SKILLS AND THE PRE-MODERN ECONOMY IN THE EAST AND THE WEST: ESSAYS DEDICATED TO THE MEMORY OF S.R. EPSTEIN 336 (Maarten Prak \& Jan Luten Van Zanden eds., Brill 2013). This may have been because pre-eighteenth century type wore out quickly. FEBVRE \& MARTIN, supra note 136, at 110-11. Worse, the tactic would not have protected the most valuable titles. Instead, copyists would have entered the market as soon as the expected duopoly profit exceeded their typesetting cost.

147. The knock-off copies typically sold for half the original price. See FEBVRE \& MARTIN, supra note 136, at 240. Most were riddled with typos, mistranslations, and crude summarizations. See HowARD, supra note 74, at 101.

148. See generally FEBVRE \& MARTIN, supra note 136, at 240 ("To some extent this practice inhibited enterprise, since the better printers always feared that if they produced a good quality edition it would promptly be copied in an inferior form at half the price, leaving them with their more expensive product unsold.").

149. See id. at 242.

150. See BOWKER, supra note 85 , at 15.

151. See HowARD, supra note 74 , at 75 .

152. These regularly exceeded actual printing costs. See PUTNAM, supra note 80 , at 412 ; see also id. at 391 (editing costs included large investments to find, purchase, and correct authenticated manuscripts for typesetting); Howard, supra note 74, at 61 (describing Manutius' landmark editions of Virgil).

153. PUTNAM, supra note 80 , at 394-95 (discussing royalties paid to Erasmus (d. 1536)).

154. See generally Howard, supra note 74 , at 98 (describing the Elzevier family who dominated Dutch publishing for 132 years). 
books everywhere. ${ }^{155}$ This condition no longer held after 1640 when Europeans began demanding books in their own languages. ${ }^{156}$ By 1660 , the big European market had fragmented into a series of national markets. ${ }^{157}$ This meant that the big Dutch publishers could no longer use economies of scale to suppress copyists, and piracy abruptly worsened after $1650 .^{158}$

Ancient book manufacturing had been scattered across thousands of scribes. Like modern samizdat, this would have been nearly impossible to stamp out. ${ }^{159}$ Print technology was different; its scale economies ensured that presses were few in number and also too valuable to risk confiscation. This created a target for regulation. Strangely, the earliest copyright laws focused on censorship and ignored economic incentives. ${ }^{160}$ To the extent that the laws had any economic purpose at all, they rewarded foreign printers for introducing the new technology and shielded local printers from imports. ${ }^{161}$

The increase in piracy after 1650 changed all that. ${ }^{162}$ In the United Kingdom, publishers fought back by organizing more aggressive cartels. ${ }^{163}$ This refocused debate on the use of monopoly as a reward to publishers and led to the Statute of Anne in $1710 ;^{164}$ from there, the idea spread across Europe. ${ }^{165}$ Crucially, the new copyright laws provided protection for a fixed number of years, ${ }^{166}$ severing the old tie between protection and first editions. ${ }^{167}$ Publishers responded by gambling on multiple titles in hopes that one or two

155. See, e.g., id. (describing the Elzevier family's focus on international sales).

156. See FEBVRE \& MARTIN, supra note 136, at 243.

157. See id.

158. Id.

159. See supra note 71.

160. Lyman Ray Patterson, Copyright in Historical PERSPECtive 36 (1968) (English government focused on censorship and was nearly "indifferent to private ownership of copy.")

161. Id. at 22-24. See also BOWKER, supra note 85 , at 13,18 (describing local content laws in Venice and France).

162. The Stationers Guild used the Crown's censorship legislation to impose their own muchmaligned cartel for 150 years. When Parliament allowed copyright to lapse in 1695, the Stationers fought back by lobbying for new legislation on purely economic grounds. The Statute of Anne (1710) tried to balance protection against monopoly by limiting copyright to twenty-eight years. Alexander, supra note 114, at 1357, 1359 (2010).

163. Members routinely organized group boycotts against booksellers who sold illicit copies. See id. at 1358-59.

164. See id. at 1359; An Act for the Encouragement of Learning (Statute of Anne), 1710, 8 Ann., c. 19 (1710) (Gr. Brit.), available at http://avalon.law.yale.edu/18th_ century/anne_1710.asp).

165. See, e.g., B. Zorina Khan, An Economic History of Copyright in Europe and the United States, ECONOMIC HISTORY ASSOCIATION, http://eh.net/encyclopedia/an-economic-history-ofcopyright-in-europe-and-the-united-states/ (last visited Nov. 24, 2014) (describing the history of copyright in France after the Statute of Anne).

166. Alexander, supra note 114 , at 1359 .

167. See id. (arguing that the new copyright statutes "revolutionized" the legal conditions under which booksellers operated). 
would succeed. The Statute of Anne produced an explosion of publishing, ${ }^{168}$ leading to a fourfold increase in English titles by the 1780s. ${ }^{169}$ Falling production costs in the nineteenth and twentieth century ${ }^{170}$ led to more demand, more titles, and more search problems.

Copyists had long specialized in producing down-market versions of popular titles. ${ }^{17}$ Copyright let publishers invade this business, ${ }^{172}$ allowing them to charge high prices to readers who wanted the durability and beauty of a first edition and low prices to everyone else. ${ }^{173}$ Twentieth century publishers updated the practice by launching paperback editions a year or so after initial, hardback publication. ${ }^{174}$ In both cases, the tactic increased publisher profits while offering low prices to readers who would otherwise have been priced out of the market. This softened copyright's downside and enhanced its social efficiency.

The physical costs of making and storing books were also important. Even though they suppressed readership, they were surprisingly helpful for search. This Article has already argued that Roman consumers would have seen large bookstore inventories as evidence of quality. ${ }^{175}$ Early modern readers extended this logic by asking how many times publishers had typeset new editions ${ }^{176}$ or how many copies stores bought for their shelves.

168. See SHER, supra note 1, at 2; Alexander, supra note 114, at 1355 (publications grew two percent per annum from 1740 to 1800 ).

169. Laura Boyle, Subscription Libraries and the Rise of Popular Fiction, JANE AUSTIN.CO.UK (June 20, 2011 (the last two decades of the eighteenth century resulted in a 400 percent increase in book publishing), available at, http://www.janeausten.co.uk/subscriptionlibraries-and-the-rise-of-popular-fiction/.

170. New inventions cut paper costs by 30 percent in 1801 although UK taxes kept paper prices high until 1861 . HOWARD, supra note 74 , at 125 . Automated machinery increased the rate at which printers could set type from 6,000 characters per hour in 1840 to 10,000 characters at the end of the century. Id. at 128 .

171. HOWARD, supra note 74, at 101.

172. Publishers usually sold large format "quartos" to wealthy patrons and then waited several years before publishing cheaper "octavo" editions. See SHER, supra note 1, at 82-83.

173. Readers' refusal to wait for cheap editions provides a striking example of the "Pac-Man Conjecture" in economics, i.e. that durable goods monopolists can exercise price discrimination by reducing prices over time. Mark Bagnoli et al., Durable-Goods Monopoly with Discrete Demand, 97 JOURNAL OF POLITICAL ECONOMY 1459, 1470 (1989). The author is indebted to the late Suzanne Scotchmer for pointing this out.

174. See Anne Trubek, How the Paperback Novel Changed Popular Literature, SMITHSONIAN.COM (Mar. 30, 2010), http://www.smithsonianmag.com/arts-culture/how-thepaperback-novel-changed-popular-literature-11893941/?all. The expanded market for low value titles like mysteries was astonishing. The hardback edition of Raymond Chandler's The Big Sleep sold a disappointing 4,000 copies in its first nine months. The paperback sold 300,000 copies. TONY Williams, A MYSTERIOUS SOMETHING IN THE LIGHT: RAYMOND CHANDLER, A LIFE 175, 178 (2012). For the current state of so-called "windowing" strategies, see U.S. v. Apple, Inc., 952 F. Supp. 2d 638, 701-02 (S.D.N.Y 2013).

175. See supra Part III.C.

176. See SHER, supra note 1, at 89. Unfortunately, publishers could and did lie about this. Id. 
Publishers and bookstores also incurred significant storage costs. ${ }^{177}$ Indeed, eighteenth century bookshops were piled to the rafters with unsold inventory. ${ }^{178}$ By the late twentieth century superstores typically stocked about one hundred and fifty thousand titles, ${ }^{179}$ most of which sold less than one copy per quarter. ${ }^{180}$ This forced stores to continually reevaluate the chances of selling a title against returning it to the publisher. Publishers were similarly forced to decide whether returned books should be stored or destroyed. ${ }^{181}$ These decisions made the presence of a title on store shelves or publisher backlists a powerful recommendation.

But physical costs also limited the time that slow-selling titles could remain on the market. The dilemma was especially sharp for movies. Most theaters must attract seven hundred and fifty viewers per week to earn a profit. ${ }^{182}$ Early twentieth century studios owned their own theaters and could ignore this constraint if they thought a title would catch on. ${ }^{183}$ This ended after the U.S. Justice Department broke up the chains in the mid-twentieth century. $^{184}$

177. In one early example, the printer Plantin (d. 1589) rented storage so that he could offer unsold fair books year after year. HowARD, supra note 74, at 76-77.

178. $I d$. at 97.

179. Jeffrey A. Trachtenberg, E-Books Rewrite Bookselling, WALL ST. J. (May 21, 2010) http://online.wsj.com/articles/

SB10001424052748704448304575196172206855634. The exact number varies between 100,000 and 250,000 titles depending on the store. See Brynjolfsson et. al., supra note 34, at 1589 .

180. ANDERSON, supra note 2 , at 7 . Half of the top 10,000 book and CD titles in a typical superstore sell less than one copy every three months. Id.

181. Bookseller purchases became much less convincing after publishers agreed to repurchase unsold books in the 1930s. See Lynn Neary, Publishers Push for New Rules on Unsold Books, NPR (June 13, 2008, 6:00 AM), http:/www.npr.org/templates/story/story/.php?storyID-91461568.

182. ANDERSON, supra note 2, at 17 . A big-budget Broadway play breaks even at about $\$ 750,000$ per week. A full house earns twice as much. See Stefanie Cohen, Spider-Man Turning to Dark, WALL ST. J., Nov. 19, 2013, at A19, available at http://online.wsj.com/news/articles/SB10001424052702303531204579206490035959108\#printMo de (describing financial constraints for the Broadway musical "Spider Man: Turn Off the Dark").

183. Raymond Chandler argued that the system ensured that the public would watch anything the studios produced: In one novel, Chandler's hero runs into a sinister mogul who explains the system:

The motion picture business is the only business in the world in which you can make all the mistakes there are and still make money ... You have to have fifteen hundred theaters .... Most expensive talent in the world. Give them anything they like, all the money they want. Why? No reason at all. Just habit. Doesn't matter a damn what they do or how they do it. Just give me fifteen hundred theaters.

Raymond Chandler, The Little Sister at p. 306 in CHANDLER: LATER NovELS \& OTHER WRITINGS (Library of America: 1995). Chandler was almost certainly exaggerating when he argued that the studios could force movies onto an unwilling public. If nothing else, the studios competed with each other.

184. See United States v. Paramount Pictures, Inc., 334 U.S. 131, 140 (1948). 


\section{THE SEARCH ECOSYSTEM}

Modern copyright gave publishers a powerful incentive to find titles that pleased consumers. This was true even when they had to share the reward with other institutions.

\section{A. Publishers and Editors}

Early printers earned slim profits ${ }^{185}$ and needed outside financing to cover the large up-front costs of printing. ${ }^{186}$ This gave investors, soon to be known as publishers, the power to decide which books would be printed. ${ }^{187}$

The early modern print era featured falling costs and bigger distribution networks. ${ }^{188}$ This made it profitable to print more titles ${ }^{189}$ despite somewhat riskier sales. While the classics continued to sell ${ }^{190}$, publishers began diversifying into sagas, folk songs, Bible stories, music, prophecy, ${ }^{191}$ calendars, almanacs, ABCs, prayer books, and religious tracts. ${ }^{192}$ The emergence of modern copyright statutes that extended protection beyond the first edition made these gambles much more favorable. By the eighteenth century, publishers were earning most of their profits on just one-third of their titles. ${ }^{193}$

One way to reduce risk was to make Martial's market less fickle. This meant picking good titles and seeding the market with enough readers to get a

185. Printing was highly competitive since presses were relatively cheap and could be rented. See FEBVRE \& MARTIN, supra note 136, at 110 . At the end of the fifteenth century there were approximately sixty printers in Paris and forty presses in Lyon. HowARD, supra note 74, at 50.

186. See FEBVRE \& MARTIN, supra note 136 , at 115.

187. One popular eighteenth century model tried to limit publishers' role by raising start-up money directly from readers. The subscribers were later allowed to buy the book at a deep discount. HOWARD, supra note 74 , at 96 . Twenty-first century studios have revived the model to "crowdsource" movie financing. See generally Lucas Shaw, Warner Bros. to Refund Angry Veronica Mars Contributors, THE WRAP (March 15, 2014), http://www.thewrap.com/warner-brosrefund-veronica-mars-contributors-download.-flixster-ultraviolet-problems/(describing "crowdfunded" movie "Veronica Mars")

188. See generally Raven, supra note 168 , at 85 ("[P]opular literature was reduced in price by the mass production and reprinting of books and magazines in the late eighteenth century, and even more notably after the advent of steam-powered printing in the early nineteenth century ....").

189. The process was reversed during the Second World War, when paper rationing slashed the number of books that publishers could offer. Wartime runs suppressed new authors and made established authors even more dominant. See Alexandra Mullen, The Escape Artist; Georgette Heyer Called Her Novels 'Nonsense'-But Sometimes Trifles Make Perfection, WaLL ST. J. (Jan. 11, 2013), http://online.wsj.com/news/articles/SB10001424127887324391104578227601475336158; see also George Orwell, As I Please, TRIBUNE, (June 30, 1944), available at http:/ttelelib.com/authors/O /OrwellGeorge/essay/tribune/AsIPlease19440630.html.

190. See, e.g., PUTNAM, supra note 80 , at 78 (discussing continued sales of church fathers into the eighteenth century).

191. Id. at 286

192. FEBVRE \& MARTIN, supra note 136 , at 216.

193. SHER, supra note 1, at 91-92 (114 of Sher's sample of 360 eighteenth century Scottish works went through four or more British editions and "were usually quite profitable"). 
fair hearing. ${ }^{194}$ Ads were an obvious way to do this. ${ }^{195}$ Then as now, the campaigns were timed to peak when the book reached store shelves. ${ }^{196}$ After that, wise publishers let "big talkers and social networks," who were far more trusted than any newspaper ad, spread the word. ${ }^{197}$ Plainly, the strategy worked because twentieth century authors routinely accepted lower royalties to work with publishers who could get the authors' works noticed. ${ }^{198}$

Publishers also helped authors write better books. By the eighteenth century publishers were hiring expert "literary counsellors" and "triers" to evaluate and sometimes revise potential titles to make them more popular. ${ }^{199}$ By the twentieth century, these duties had expanded to include discovering new authors, ${ }^{200}$ suggesting improvements, ${ }^{201}$ and helping promising authors overcome poor initial sales. The system's beneficiaries included F. Scott Fitzgerald, Ernest Hemingway, Thomas Wolfe, Alan Paton, James Jones, Isaac Bashevis Singer, Joseph Brodsky, Nadine Gordimer, Seamus Heaney, ${ }^{202}$ Ring Lardner, ${ }^{203}$ Raymond Chandler, ${ }^{204}$ Anne Tyler, and Elmore Leonard. ${ }^{205}$ Determined editors almost certainly saved some of these names from oblivion. ${ }^{206}$

194. Cf. SHER, supra note 1 , at $138-39$ and 283 (describing how publishers paid bonuses for promising titles and gave free "presentation copies" to influential readers).

195. In the eighteenth century these regularly exceeded fifteen percent of the book's manufacturing costs. SHER, supra note 1 at 362 .

196. Id. at $361-62$.

197. Elie, supra note 18.

198. Farrar, Strauss \& Girard's titles "became classics in no small part because FSG was the publisher and valued quality over quick profits. Hundreds of authors have passed up more money offered elsewhere to get a piece of the house's prestige and its hands-on approach to editing and publicity." Id.

199. SHER, supra note 1 , at 283. There were, of course, precedents. The ancient publisher Atticus is said to have provided "all the services of a high-class publisher" including careful revisions, criticism of style or content, discussing the advisability of publication or the suitability of a title, organizing private readings of the new book, sending out complimentary copies, and organizing distribution. REYNOLDS \& WILSON, supra note 70, at 24. Editors in the modern sense first appeared in the seventeenth century but were usually friends of the author. Howard, supra note 74 , at 94 .

200. This process was facilitated by literary agents who were only paid when the author received royalties. The arrangement amounted to a prize system with editors as judges.

201. See, e.g., Ian Linton, The Duties and Responsibilities of Editors, HOUSTON CHRONICLE, http://work.chron.com/duties-responsibilities-editors-13679.html (last visited Nov. 15, 2014) (discussing how editors help authors adjust their works to suit the market).

202. Elie, supra note 18.

203. RING LARDNER, RING AROUND MAX: THE CORRESPONDENCE BETWEEN RING LARDNER \& MAX PERKINS (Clifford Caruthers ed., 1973).

204. See WILLIAMS, supra note 174 , at 142.

205. Trachtenberg, supra note 91.

206. Id. 


\section{B. Bookstores.}

Ancient publishers sold their books both to individuals and stores. ${ }^{207}$ Since the number of first editions was fixed, stores could demand a higher price if a title later became popular. This mini monopoly rewarded stores that tracked their customers' tastes and marketed new titles. ${ }^{208}$

By the eighteenth century, publishers were selling most of their books through stores. ${ }^{209}$ This was efficient since stores possessed information about local readers that no outsider could match. The fact that stores bought books from multiple publishers ${ }^{210}$ provided a further assurance that their recommendations were impartial. ${ }^{21}$

Early print era publishers took years to organize each new edition. ${ }^{212}$ As in Roman times, this meant that stores received part of the publisher's monopoly every time they purchased a book for inventory. This continued until Victorian technology made it easy for publishers to store plates so that new "impressions" could be printed quickly. ${ }^{213}$ Twentieth century publishers restored bookstore incentives by offering them a fixed percentage of the suggested retail price. ${ }^{214}$

\section{Libraries}

At first, only wealthy readers could afford books, ${ }^{215}$ but this changed when booksellers began renting books to customers in the late seventeenth century. ${ }^{216}$

207. AVRIN, supra note 74, at 171. ("In Cicero's day, the first century B.C.E, bookstores were located in the Roman forum .... Even provincial towns like Brindisi, Ilerda ... Carthage, Lyons and Reims had bookshops anxious to keep up with what was being read in the capital."); IDDENG, supra note 57, at 69 (describing Pliny's pleasure at hearing that his book was for sale in a Lyon store).

208. At the same time, dividing the monopoly between publishers and stores invited a phenomenon that economists call "double marginalization." This led to pathologically high prices that scared off readers and suppressed profits. See JEAN TIROLE, THE THEORY OF INDUSTRIAL ORGANIZATIONS 174-75(1988).

209. Cf. Lauren Gilbert, Libraries in Georgian and Regency England, ENGLISH HISTORICAL FICTIONAL AUTHORS (Jan. 15, 2012), http://englishhistoryauthors.blogspot.com/2012/01/librariesin-georgian-and-regency.html ("In the 18 th century, the marketing of literature evolved from private patronage to publishing by booksellers.").

210. Some booksellers manufactured part of their stock in-house. See HOWARD, supra note 74 , at $96-97$.

211. This was diluted by side-agreements in which publishers paid booksellers to advertise their titles. See id.

212. See, e.g., The History of Letterpress Printing, ELATION PRESS (Sept. 19, 2014), http://elationpress.com/resources/the-history-of-letterpress-printing/ (Gutenberg's Bible took two to three years to complete).

213. The History of Letterpress Printing, supra note 212.

214. This had the added advantage of eliminating double marginalization.

215. See Gilbert, supra note 209.

216. See id. 
The first English circulating library opened in $1730,{ }^{217}$ and there were five hundred and forty of them by the middle of the nineteenth century. ${ }^{218}$ These could be commercial, member-owned, ${ }^{219}$ or attached to private clubs. ${ }^{220}$ Regardless, libraries that provided honest, high quality advice gave more value and could extract higher fees from customers. ${ }^{221}$ This was done by hiring clerks who could suggest promising titles to readers. ${ }^{222}$

The first nationwide player was called Mudie's Select Library. ${ }^{223}$ It dominated the British market from 1842 to $1894 .{ }^{224}$ Mudie's could make author reputations faster than any newspaper, ${ }^{225}$ and sometimes purchased entire print runs. ${ }^{226}$ This gave it more than enough power to overcome the vagaries of Martial's market. Retailers Boots, Harrods, and W.H. Smith replaced Mudie's in the $1890 \mathrm{~s}^{227}$ Large retailers remained a dominant force in British publishing through the first half of the twentieth century. ${ }^{228}$

Americans were wealthier and had less need to pool book purchases; however, they still needed help finding titles. The Book of the Month Club, established in 1926, earned a profit by convincing subscribers that it was "a sound selector of good books" and had 550,000 members by World War II. ${ }^{229}$

217. Laura Boyle, Subscription Libraries and the Rise of Popular Fiction, THE JANE AUSTEN CENTER (June 20, 2011), http://www.janeausten.co.uk/subscription-libraries-and-the-rise-ofpopular-fiction/.

218. Id.

219. See Guinevere L. Griest, Mudie's Circulating LibraRy and the Victorian NOVEL 8 (1970).

220. The publisher J.A. Spender put a young Raymond Chandler up for membership in the National Liberal Club so that Chandler could use the reading room. WILLIAMS, supra note 174, at 41.

221. See, e.g., Kathryn Kane, Regency Circulating Libraries-Why, How and Who?, THE REGENCY REDINGOTE, (June 21, 2011), http://regencyredingote.wordpress.com/2011/ $10 / 21 /$ regency-circulating-libraries-why-how-and-who/ ("[L]ibrary clerks made it a point to be knowledgeable about all the newest novels in order to best serve their patrons.").

222. The most famous clerk was almost certainly George Orwell, who novelized his experiences in Keep the Aspidistra Flying (1939). See Gordon Bowker: Orwell's Library, THE ORWELL PRIZE, http://theorwellprize.co.uk/george-orwell/about-orwell/gordon-bowker-orwellslibrary/ (last visited Nov. 15, 2014).

223. See GRIEST, supra note 219 , at 1 .

224. George P. Landow, Book Review, 69 MODERn PHILology 367, 367 (1972), available at http://www.jstor.org/stable/pdfplus/436861.pdf?\&acceptTC=true\&jpdConfirm=true.

225. See generally id. at 367-69 (quoting GRIEST, supra note 219 , at 20) (explaining that Mudies' advertising and list of "the principal New and Choice Books in circulation" could make new author reputations faster than newspaper reviews).

226. Id. at 367.

227. See GRIEST, supra note 219 , at 26-27.

228. As George Orwell remarked, "It is book-borrowing and not book-buying that keeps authors and publishers alive." Orwell, supra note 222. The last Boots libraries closed in the 1960s. GRIEST, supra note 219 , at xi.

229. See Yukie Ohta, When the BOMC Was the BOMC: The Beginnings of the Book of the Month Club, NEW YORK BOUND BOOKS (Nov. 2, 2013), http:/www.newyorkboundbooks.com/2013/11/02/when-the-bomc-was-the-bmoc/. 
The rise of video stores in the 1980s provides an even closer analogy to British libraries. ${ }^{230}$

\section{Third Party Influencers: Governments, Aristocrats, Scholars, and Critics}

Individuals and institutions have always tried to influence authors and public taste. Market forces began to erode these influences in the seventeenth and eighteenth centuries. ${ }^{231}$

As in Roman times, early modern publishing was heavily dependent on nonmarket actors like schools, ${ }^{232}$ patrons, ${ }^{233}$ and governments. ${ }^{234}$ This gave elites significant leverage over what authors wrote and readers read. ${ }^{235}$ This situation changed in the eighteenth century when deserving authors began finding sinecures in universities or the church. ${ }^{236}$ The new institutional arrangement insulated authors from day-to-day interference and gave them more room to follow their conscience. ${ }^{237}$ At the same time, it also made it easier for them to pursue market signals from publishers and the book-buying public. ${ }^{238}$

230. See Richard Roehl \& Hal R. Varian, Circulating Libraries and Video Rental Stores, FIRST MONDAY (May 7, 2001), http://firstmonday.org/ojs/index.php/fm/article/view/854/763.

231. See SHER, supra note 1, at 208.

232. Student texts similarly dominated medieval publishing and commanded large print runs into the 18th C. See e.g., FEBVRE \& MARTIN, supra note 136, at 219 (describing large printer Plantin's production of scholarly works). Indeed, French authorities leveraged their control of the university market to demand censorship of all titles including those sold to the general public. PUTNAM, supra note 80, at 204-05, 214-15. Twenty-first century textbooks still account for twentyfive percent of all US publishing revenues. Thad Mcllroy, The Future of Book Publishing, THE FUTURE OF PUBLISHING, http://thefutureofpublishing.com/industries/the-future-of-book-publishing/ (last updated Aug. 1, 2013). The difference today is that textbooks have almost no sales or cultural impact in the wider society.

233. The great majority of authors have always needed—and still need-outside income to write. Aristocratic patrons filled this gap from Roman times to the seventeenth century. JOHNSON, supra note 67, at 42-56; Anthology of English Literature: Edmund Spenser, LUMINARIUM, http://www.luminarium.org/renlit/spensbio.htm (last visited Nov. 16, 2014) (listing English poet Edmund Spenser's patrons); PUTNAM, supra note 80, at 377-88 (discussing the importance of Italian, French, and English patrons to early printers).

234. Government support remained important into early modern times, especially in France. PUTNAM, supra note 80 , at 378 .

235. See generally id. at 377-78 (discussing the influence and support of wealthy patrons, universities, and governments on early printing).

236. The sinecures typically included jobs in government, universities, and the church. SHER, supra note 1 , at 205, 208-09. The transition was less abrupt than it seems since many eighteenth century appointments were controlled by influential aristocrats. Id.

237. See id. at 209.

238. See generally id. at 260-61 (discussing how "enlightened patronage" allowed authors the freedom to rely on support from publishers and the public). 
The rise of newspapers in the seventeenth century ${ }^{239}$ made market forces even more influential. Newspapers understood that their revenues depended on providing value to readers, and this included giving readers reliable advice about titles that would please them. ${ }^{240}$ The explosion of titles following the Statute of Anne led to specialized journals-such as the Monthly Review-to help the public find books. ${ }^{241}$ Elites fought back by publicizing their own tastes through book prizes. ${ }^{242}$ These also contained a market component, however, since prizes that failed to boost sales were less prestigious. ${ }^{243}$

\section{The THIRD Age of SEARCH: THE StORY So FAR}

The rise of the Internet radically expanded book markets. ${ }^{244}$ As always, more sales meant more titles. By 2003, Amazon readers had more than 2.3 million titles to choose from. ${ }^{245}$ The introduction of e-books accelerated the trend by reducing publishers' overhead costs. ${ }^{246}$ The resulting proliferation of titles made the search problem even worse. Despite revolutionary online tools, search institutions have failed to keep up.

\section{A. Reconnecting With Audiences}

The rise of movies in the early twentieth century encouraged publishers to find new ways of picking winners. Moviemaking requires teams of artists who frequently disagree about creative choices. In principle, financiers, now called "studios" and "producers," 247 could break the deadlock ${ }^{248}$ by deciding which

239. Mitchell Stephens, History of Newspapers For Collier's Encyclopedia, www.nyu.edu/classes/stephens/Collier\%27s\%20page.htm (last visited Nov. 16, 2014).

240. The system was far from perfect. Reviewers were often literati who tradeded favors or powerful publishers who lobbied newspapers to puff their authors and denigrate competitors. See SHER, supra note 1 , at 137,366 . By comparison, twentieth century corruption seems to have been limited to free dinners. See Fadiman, supra note 44, at 477.

241. SHER, supra note 1 , at 4.

242. See Ishmael Reed, Do Book Awards Matter?, Wall ST. J. (Nov. 23, 2013), http://blogs.wsj.com/speakeasy/2013/11/23/do-book-awards-matter/.

243. See id. (discussing history of The Before Columbus Foundation and the American Book Awards).

244. See generally Brynjolfsson, supra note 34, at 1580 (reporting that Amazon stocks 23 times more book titles than a typical Barnes $\&$ Noble).

245. Id. at 1581. Amazon also offered 250,000 CDs compared to 5-15,000 for a brick and mortar store. $I d$.

246. See generally Trachtenberg, supra note 91 (documenting reduced overhead of e-books compared to paper editions).

247. Raymond Chandler, Writers in Hollywood, in CHANDLER: LATER NOVELS \& OTHER WRITINGS 997 (1995) ("In so far as the writing of the screenplay is concerned, however, the producer is the boss; the writer either gets along with him and his ideas (if he has any) or gets out.").

248. Id. at 994 (screenwriters work "under the supervision of a producer . . charged with the salability and soundness of the project."). 
artists were right. ${ }^{249}$ Not surprisingly, moviemakers began searching for less subjective methods for deciding what audiences wanted.

By the early twentieth century, Hollywood was developing survey methods that showed test audiences "sneak previews" of new movies. ${ }^{250}$ The studios used this information to cut or add scenes that would make the movie more lucrative. However, it was hard to recruit viewers who matched the self-selected audiences that would actually come to see the film. ${ }^{251}$ This sometimes produced spectacular mistakes. ${ }^{252}$ Television evaded this restriction by showing sample programs, called pilots, to the entire population. ${ }^{253}$ In theory, this let twentieth century television executives reach more viewers in a single evening than Homer had in centuries. ${ }^{254}$ Unlike Homer's audiences, however, television viewers were little more than passive surveillance targets. This made their input much less valuable. ${ }^{255}$

Consumers were similarly hungry for objective measures of quality. Twentieth century publishers responded by compiling bestseller lists for books, weekend box office reports for movies, and Top 40 playlists for music. But the system was unreliable. After all, most sales reported purchasing decisions made by consumers who had not yet read the book or seen the movie. ${ }^{256}$ This allowed

249. Id. at 994. ("Hollywood is a showman's paradise. But showmen make nothing; they exploit what someone else has made. The publisher and the play producer are showmen too; but they exploit what is already made. The showmen of Hollywood control the making-and thereby degrade it.")

250. The audiences ranged from hand-picked focus groups up to everyone who happened to be in the theatre when a surprise screening was announced. See id. Screenings reportedly led to changes in many films including, inter alia, E.T., Pretty Woman, Fatal Attraction, and My Best Friend's Wedding. Id. The most famous sneak preview of all took place when David O. Selznick screened Gone With the Wind in Riverside, California. See Christopher Lehmann-Haupt, Books of The Times; David Selznick: A Colossus Obsessed by Self, N.Y. TIMES (Nov. 23, 1992), http://www.nytimes.com/1992/1 1/23/books/books-of-the-times-david-selznick-a-colossus-obsessedby-self.html.

251. See generally Michele Willens, FILM; Putting Films to the Test, Every Time, N.Y. TIMES (June 25, 2000), http://www.nytimes.com/2000/06/25/movies/film-putting-films-to-the-test-everytime.html (discussing how studios hire groups like the National Research Group to recruit people who match the film's hoped-for audience).

252. See generally E.T., supra note 250 (test audiences hated E.T. and wanted to cut 'Over the Rainbow' from The Wizard of $\mathrm{Oz}$ ).

253. See, e.g., Winifred Fordham Metz, How TV Production Works, How STUFF wORKS, http://electronics.howstuffworks.com/tv-production.htm (describing the process of how television show ideas become series) (last visited Nov. 23, 2014).

254. See id.

255. The fact that viewers were willing to watch a pilot confirmed that the premise was attractive but said little about how well it was executed or whether audiences would return for more. Amol Sharma, Hollywood Shuffle: Amazon Mines Its Data Trove to Bet on TV's Next Hit, WALL ST. J. (Nov. 2, 2013), http://online.wsj.com/news/articles/SB100014240527023 04200804579163861637839706 .

256. Many bestsellers are never read at all. In 1985, The New Republic placed coupons worth $\$ 5$ inside 70 copies of selected bestsellers; none were redeemed. See Bill Goldstein; Think Tank: Let Us Now Praise Books Well Sold, Well Loved but Seldom Read, N.Y. TIMES (July 15, 2000), 
even bad products to snowball in popularity until word of mouth caught up with them. ${ }^{257}$

\section{B. Vanishing Physical Costs}

Digital content eliminated the need for physical copies, stores, warehouses, and movie theaters. This slashed prices and increased the supply and availability of content to consumers. ${ }^{258}$ It also encouraged providers like Netflix, Oyster, Scribd, and Amazon Prime to update the old commercial libraries model. ${ }^{259}$ Like their eighteenth century predecessors, the new web services lived and died by recommending titles. Falling distribution prices also let titles stay on the market longer. ${ }^{260}$ Movies like A Christmas Story, It's a Wonderful Life, and Midnight Madness ${ }^{261}$ used this breathing room to build large followings. ${ }^{262}$

http://www.nytimes.com/2000/07/15/books/think-tank-let-us-now-praise-books-well-sold-wellloved-but-seldom-read.html.

257. The lists were also surprisingly vulnerable to tampering. In 1995, authors Michael Treacy and Fred Wiersema reached number eight on the New York Times Best Seller List by buying 10,000 copies of their own book. Did Dirty Tricks Create A Best Seller?, BloOMBERG BUSINESSWEEK (Aug. 6, 1995), http://www.businessweek.com/stories/1995-08-06/did-dirty-trickscreate-a-best-seller. Top 40 music was famously hijacked in the "Payola Scandal" of the 1950s. Gabriel Rossman, Climbing the Charts: What Radio airplay Tells Us about the DIFFUSION OF INNOVATION 25 (2012).

258. See Trachtenberg, supra note 179.

259. Netflix offers an ever-changing assortment of streaming video for a flat monthly fee. Oyster, Scribd, and Amazon Prime offer a similar service for books. See David Streitfeld, As New Services Track Habits, The E-books are Reading You, N.Y. TIMES, Dec. 24, 2013, at A1, available at http://www.nytimes.com/2013/12/25/technology/as-new-services-track-habits-the-e-books-arereading-you.html?pagewanted=all\&_r $=0$.

260. See generally Trachtenberg, supra note 179 (explaining why e-books that don't require "paper, printing presses, storage space, or delivery trucks" can be sold more cheaply than books from a brick-and-mortar store).

261. See Spencer Jakab, Flop at the Box Office Spawns a Generation of 'Midnight Madness', WALL ST. J. (Sept. 18, 2013), http://online.wsj.com/news/articles/SB10001424127 887323527004579081271127180490; see also Matt Hickman, 6 Things You Probably Didn't Know About 'It's a Wonderful Life,' MOTHER NATURE NETWORK (Dec. 14, 2011), http://www.mnn.com/lifestyle/arts-culture/stories/6-things-you-probably-didnt-know-about-its-awonderful-life (discussing how It's $A$ Wonderful Life flopped at the box office but later became popular from television exposure in the 1970s and 1980s ); Gary Susman, How 'A Christmas Story' Went From Cult Movie to Holiday Classic in 30 Years, Moviefone (Nov. 18, 2013), http://news.moviefone.com/2013/11/18/christmas-story-holiday-classic/ (discussing how $A$ Christmas Story did poorly in movie theaters but later become popular on television).

The fact that two of the examples are Christmas movies points to a special problem for word of mouth networks that only operate two weeks out of the year.

262. Examples of theatrical flops that later became profitable on DVDs or television include Sahara (2005), The Alamo (2004), Heaven's Gate (1980), Alexander (2004), Beloved (1998), and Poseidon (2006). See Greatest Box Office Bombs, supra note 45. 
These were welcome developments. Even so, lower inventory costs deprived consumers of important information. ${ }^{263}$ The corner bookstore with its limited shelf space could not survive without finding books that consumers wanted. ${ }^{264}$ But its online successors possess nearly infinite space. ${ }^{265}$ This means that the online retailers can afford to be indiscriminate-and consumers know it.

\section{Enter the Web}

Falling communication costs made it easier for consumers to form and operate word of mouth networks. ${ }^{266}$ They also vastly expanded publishers' ability to collect and analyze large data sets. ${ }^{267}$ The breakthrough Blair Witch Project, released in 1999, showed that the new word of mouth networks could make even obscure movies successful. ${ }^{268}$ Simple extensions of the idea include websites that let readers write blogs, participate in forums, assign star ratings, write reviews, and list favorite or related titles. ${ }^{269}$

Cheaper communication also helped publishers and studios. Hollywood routinely uses crowdsourcing to find screenplays, ${ }^{270}$ judge project potential, ${ }^{271}$ and line up investors. ${ }^{272}$ Authors similarly use the web to learn the preferences

263. See generally Brynjolfsson, supra note 34, at 1581 (comparing online retailers' 2.3 million available books to a traditional brick-and-mortar store's 40,000 to 100,000 titles).

264. See id. (describing how online retailers bring nearly unlimited choices to "every shopper's desktop").

265. See id. For example, ABEBooks.com lets individuals post and sell books for a monthly subscription fee. See also Become a Bookseller on ABEBooks, ABEBOOKS.COM, http://www.abebooks.com/books/Sell/professional-sellers.shtml (last visited Nov. 17, 2014).

266. See generally William McGeveran, Disclosure, Endorsement, and Identity in Social Marketing, 2009 U. ILL. L. REV. 1105,1109 (2009) ("'Word of mouth' describes peer-to-peer interactions in which an individual passes on opinions about a product to others.").

267. Id. at 1112 .

268. See Alexandra Wolfe, Penn Jillette of Penn \& Teller: A Few New Tricks, WALL ST. J. (Dec. 6, 2013), http://online.wsj.com/news/articles/SB100014240527023048548045792362117260 48766 (arguing that the Blair Witch Project became popular because of internet fan groups).

269. See also Daniel Nations, Book Social Networks: A List of Social Networks for the Booklover, ABOUTTECHNOLOGY, http://webtrends.about.com/od/socialnetworks/tp/book-socialnetwork-list.htm (last visited Oct. 18, 2014) (listing various websites where consumers share promising titles and book reviews). See generally GOODREADS, http://www.goodreads.com/ (last visited Nov. 17, 2014) (on-line reader participation site).

270. See, e.g., Sharma, supra note 255 (describing how Amazon uses viewer data to produce better screenplays).

271. Several studies have shown that crowds are roughly as accurate as individual experts. This is still a long way from doing better, i.e., overcoming Goldman's objection that "nobody knows anything." Martin Spann \& Bernd Skiera, Internet -Based Virtual Stock Markets for Business Forecasting, 49 MGMT. SCI. 1310, 1319-23 (2003) (analyzing "Hollywood Stock Exchange" fantasy market's ability to predict box office earnings). See generally Màrton Mestyàn et. al, supra note 5, at 3-4 (discussing how Wikipedia and similar websites can help predict society's reaction to movies).

272. See, e.g., Wolfe, supra note 268 (discussing Penn Jillette's efforts using crowdfunding to finance a movie). 
of readers, elicit new ideas, ${ }^{273}$ and market new titles. ${ }^{274}$ The only place where crowdsourcing has failed is in the area of authorship. Even in the Digital Age, the old arguments against screenwriting by committee still hold. ${ }^{275}$

Given enough computing power, publishers can dispense with markets and target individuals directly. ${ }^{276}$ This is nothing new since even Roman bookstores must have made a point of knowing their readers. The difference today is that this can be done for millions of readers at a time. The new data is also more intimate since e-booksellers like Barnes \& Noble or Amazon are notified each time readers turn a page, insert a bookmark, or highlight text. ${ }^{277}$ This tells them which titles are devoured, skimmed, or ignored and is only a short step from knowing how much consumers would pay for titles in the first place.

When information about individuals is limited, publishers must fall back on other methods that gather data for well-defined groups. Falling information costs have made it easy to collect monitoring and surveying data for movies ${ }^{278}$ and books ${ }^{279}$ in unprecedented detail. Content providers have even used

273. See generally Scott Adams to Try Crowd-Sourcing Dilbert's Jokes, TECHDIRT (Apr. 22, 2008), http://www.techdirt.com/articles/20080422/011356910.shtml (describing how cartoonist Scott Adams uses fan input to suggest jokes and supply punch-lines for uncompleted strips).

274. One of the most straightforward methods involves paying readers to write reviews. $C f$. DUNCAN J. WATTS, EVERYTHING IS OBVIOUS-ONCE YOU KNOW THE ANSWER 189-93 (2011) (describing various paid review systems). This increases word-of-mouth recommendations while showing that the publisher has enough faith in the title to risk negative reviews.

275. The best-known example is Snakes on a Plane, which asked fans to make creative choices even when this forced the producers to reshoot key scenes. The film earned a paltry $\$ 13$ million in its first weekend and just $\$ 34$ million overall. See Spencer Kornhaber, 'Snakes on a Plane,' 5 Years Later, THE ATLANTIC (Aug. 18, 2011), http://www.theatlantic.com/entertainment/ archive/201 1/08/snakes-on-a-plane-5-years-later/243790/; see also Snakes on a Plane, BOX OFFICE MOJO, http://www.boxofficemojo.com/movies/?page=weekend\&id=snakesonaplane.htm (last visited Nov. 17, 2014). As one observer noted, "The people who influenced the script weren't fans of the movie; they were fans of the wacky title." Augie Ray, Can Influencers Be a BAD Influence?, EXPERIENCE: THE BLOG (Apr. 12 2009), http://www.experiencetheblog.com/2009/04/caninfluencers-be-bad-influence.html. By comparison, the producers of Battlestar Galactica told fans "This is the show. You may not like the show, you don't have to watch the show, but this is the show that we're making." See Adam B. Vary, The Beginning of the End: A 'Battlestar Galactica' Oral History, ENTERTAINMENT WEEKLY (Mar. 12, 2009), http://www.ew.com/ew/gallery/0,2026537620595444,00.html. Battlestar did well at the box office.

276. See generally Alexandra Alter, Your E-Book is Reading You, WaLL ST. J. (July 19, 2012), http://online.wsj.com/news/articles/SB10001424052702304870304577490950051438304 (discussing how publishers use e-reader data to determine how fast individuals read books and what type of books they prefer).

277. See Joshua Tucker, Making Sense of the Kindle's Highlighting Feature, Salon (Aug. 9, 2010), http://www.salon.com/2010/08/09/kindle_social_highlighting/. The devices also track the virtual "bookshelves" that readers construct to organize their purchases and instances in which readers "lend" particular titles to one another. See Alter, supra note 276.

278. See, e.g., Sharma, supra note 255 (describing Amazon studios' use of reader-supplied star rankings, surveys, and demographic data).

279. Streitfeld, supra note 259 (describing how online libraries Oyster and Scribd offer publishers and authors aggregate data summarizing how readers consume books and which parts they skip over). 
physiological data to discover preferences that viewers are not consciously aware of. $^{280}$

\section{The Crisis}

Printing technologies introduced large scale economies which ensured that pirates would be (a) few in number and (b) possess enough capital to fear court judgments. This provided an easy target for copyright and judicial enforcement. Today, however, nearly anyone can copy and share documents at a near-zero cost. Furthermore, the profits earned by the average copyist are much too small to justify a lawsuit. This makes enforcement nearly impossible. ${ }^{281}$ Together, these developments threaten to choke off the revenue that used to pay editors for search. In principle, radically new and more efficient information technologies could pick up the slack. In practice, the available evidence suggests that search is markedly less capable than it was a few years ago.

The decline of copyright has clearly eroded many search institutions. For example, there are now fewer brick and mortar stores where consumers can sample books and music. ${ }^{282}$ Similarly, tighter Hollywood budgets have eliminated programs that used to search for new story ideas. ${ }^{283}$

In principle, new electronic search tools could compensate for these losses. However, today's unknown authors typically sell fewer e-books than hardcovers, ${ }^{284}$ despite the fact that the latter cost twice as much. ${ }^{285}$ This strongly suggests that online search is less effective than traditional methods, particularly for unknown authors. ${ }^{286}$ There is also a market test. In 2010, Amazon let authors post new books for sale directly onto its website without a publisher. ${ }^{287}$ Despite generous revenue sharing, the initiative collapsed. ${ }^{288}$ Plainly, authors did not see online tools as an acceptable substitute for editors.

280. Emory University scientists claim that brainwave activity can predict hit songs even when listeners consciously dislike the tune. See Hotz, supra note 48.

281. In principle, the situation can be retrieved by imposing outsized, in terrorem fines on randomly chosen offenders. See 17 U.S.C. $\S 504$ (2012). But this approach is constitutionally doubtful and ultimately threatens the political consensus for copyright itself. Determining the Limits on Copyright Statutory Damages, supra note 332.

282. Trachtenberg, supra note 91.

283. Cf. Ben Fritz, For Movie Producers, A Golden Age Fades: As Hollywood Slashes Spending, Nobody Has Felt the Brunt as Much as Movie Producers, WALL ST. J. (Jan. 22, 2014), http://online.wsj.com/news/articles/SB10001424052702303819704579320690334294558.

284. See, e.g., Trachtenberg, supra note 91 (noting that one debut novel sold more than 10,000 print copies, but only 359 digital ones).

285. See Jeffery A. Trachtenberg, E-Book Readers Face Sticker Shock, WALL ST. J., (Dec. 15, 2011), http://online.wsj.com/news/articles/SB10001424052970204336104577096762173802678.

286. See Trachtenberg, supra note 91.

287. See, e.g., United States v. Apple, Inc., 952 F. Supp.2d 638, 671 (S.D.N.Y. 2013)

(describing Amazon initiative to "disintermediate" publishers from the supply chain).

288. Amazon offered authors seventy percent of all sales revenue. 
Meanwhile, publishers have become markedly less adventurous. Today's ebook sales are slanted toward brand name authors, ${ }^{289}$ while movie sales are dominated by blockbusters that exploit the name recognition of existing movies, comic books, and toys. ${ }^{290}$ This process of selecting projects because they are already well known is disturbingly Roman. Some publishing executives have even started to denigrate the twenty-first century's proliferation of titles as "clutter."291 This is just another way of saying that readers cannot sort through the choices for themselves-and that existing search institutions have failed.

\section{THE WAY FORWARD}

Martial's fickle market cannot be trusted to find the best books. Over the years, society has developed various institutional fixes. ${ }^{292}$ The Homeric system revised texts through direct interactions between authors and audiences. ${ }^{293}$ This produced great literature, but was painfully slow. The second, Library of Alexandria strategy left book production to scholars, monks, aristocrats, and government elites. This did little to find new books, especially by outsiders. Finally, commercial publishers hired expert editors to find and promote titles that readers would like. This market solution supported a vibrant array of search institutions throughout the Age of Print.

But commercial publishing is vulnerable to copyists. Indeed, the Roman example shows how even modest gaps in protection can cripple search. Modern copyright fixed the problem by extending protection beyond first editions, ${ }^{294}$ but this protection is quickly eroding. The Digital Age urgently needs new solutions.

There are three possibilities. First, commercial publishers can try to replace copyright with technical protections that raise pirates' copying costs. Second, firms can reorganize the commercial system around new players that are less vulnerable to piracy. Finally, society can dump commercial editors and return to the Homeric pattern of harvesting judgment directly from audiences.

289. Id. The decline of short stories in favor of blockbusters has been especially prominent in science fiction. Tom Shippey, Future History, WALL ST. J., Dec. 21 2013, at C6.

290. See ElBERSE, supra note 53 at 18,51 (providing a detailed history of the "blockbuster strategy"); see also Fritz, supra note 223 ("[B]rand-name franchises [are] the locus of power in the movie business ....").

291. Neary, supra note 181.

292. See, e.g., Part VI.A.

293. See PUTNAM, supra note 12 , at 66-67.

294. See supra text accompanying notes 162-169. 


\section{A. Defending Today's Publishing Model: The Limits of Technical Protection}

Technical protections have kept copying costs high for software and games. ${ }^{295}$ But books - and to a lesser extent music and movies-must be produced in a format that can be read by humans. For this reason, no technical protection can prevent Roman-style scribes from copying an e-book for about $\$ 1,000{ }^{296}$ This implies that publishers can earn no more than a few thousand dollars per title ${ }^{297}$-at least an order of magnitude less than the $\$ 30,000$ to $\$ 80,000$ that some of today's physical books earn to support editors, marketing, and search. ${ }^{298}$

In fact, the problem is worse than that. Since roughly one in fifteen books earns a profit, ${ }^{299}$ pirates can usually increase profit by limiting themselves to titles that have already become popular in the marketplace. However, spotting

295. See, e.g., So You'd Like to...Protect Your Software from Piracy, AMAZON.COM, http://www.amazon.com/gp/richpub/syltguides/fullview/RK5TOHP5F65OY (last visited Nov. 17, 2014) (describing technical protections for software).

296. Copyists can transcribe text from computer screens for about five dollars per page. See, e.g., PERFECT PAPERS TYPING SERVICE, http://www.goldminewebdesign.com/bz3_a/index.htm (last visited Nov. 17, 2014) (offering transcription services for $\$ 4.50$ per page). Using scanners can cut this cost to anywhere between ten cents and ten dollars per page. See Darnton, supra note 3. Since current OCR technologies are already mature, more computing power and/or better software probably are unlikely to change this figure materially. $C f$. JON M. BOOTH \& JEREMY GELB, OFFICE OF INNOVATION AND NEW TECH., OPTIMIZING OCR ACCURACY ON OLDER DOCUMENTS (rev. June 2006), available at http://www.gpo.gov/pdfs/fdsys-info/documents/WhitePaperOptimizingOCRAccuracy.pdf (reviewing available technology options for improving OCR). Analog music can similarly be digitized for a few hundred dollars per song. See Karp, supra note 11 .

297. Assume that pirates produce illicit editions whenever their expected revenue exceeds copying costs. Then each would-be pirate knows (a) that the pirate must split sales with the incumbents, and (b) that the books the pirate does sell will be priced below the incumbents' current price. Factor (a) suggests that the first pirate will enter the market as soon as the original publisher's expected revenues reach $\$ 2,000$. Factor (b) suggests that the actual trigger is somewhat higher.

298. Publisher margins can be inferred by comparing the price of public domain books with copyrighted titles. The Barnes \& Noble trade paperback edition of ANNA KARENINA currently lists for \$8.95. Anna Karenina (Barnes \& Noble Classics Series), BARNESANDNOBLE.COM, http://www.barnesandnoble.com/w/anna-karenina-barnes-noble-classics-series-leo-

tolstoy $/ 1105958283$ ?ean $=9781593080273$ (last visited Nov. 17, 2014). This presumably covers manufacturing, shipping, and store overhead costs. Comparable copyrighted volumes are typically twice as expensive. See, e.g., The Panther (John Corey Series \#6) by Nelson DeMille, BARNESANDNOBLE.COM, http://www.barnesandnoble.com/w/the-panther-nelson-demille/ 1108616442 ?ean $=9780446699617$ \& itm $=1$ \&usri $=9780446699617 \& \mathrm{r}=1$ (last visited Nov. 17,2014 ) (originally priced at \$15.00); Underworld: $A$ Novel: Don DeLillo, AMAZON.COM, http://www.amazon.com/Underworld-A-Novel-Don-DeLillo/dp/0684848155 (last visited Oct. 14, 2014 ) (originally priced at $\$ 18.95$ ). Part of this $\$ 7-\$ 10$ margin is used to pay author royalties, which are usually set at fifteen percent of the purchase price. Trachtenberg, supra note 91 . Assuming that fifty percent of the purchase price goes to the publisher, this leaves about $\$ 3$ to $\$ 8$ per book. See id. A book which sells 10,000 copies should therefore generate $\$ 30,000-\$ 80,000$ to support editors, search, and marketing.

299. See, e.g., Elie, supra note 18 (citing experience at Farrar, Straus, \& Giroux). 
winners takes time. This means that pirates will usually enter the market too late to match the original publisher's revenues. Even so, the net impact is disastrous. Suppose that the original publisher is lucky enough to earn $\$ 10,000$ on the fifteenth book. Because the first fourteen books earned little or nothing, this still comes to just $\$ 667$ per book - a fivefold decrease from the naïve estimate. This reintroduces the old Roman first edition problem with a vengeance.

These arguments suggest that technical protections cannot support human editors at anything like twentieth century levels. However, they might still be useful for products like software and video games that are only partly humanreadable. Here, publishers should be able to recover their production costs plus a substantial margin. ${ }^{300}$ Movies and music provide an intermediate case.

\section{B. The Return of Self-Help: Digital Bookstores}

Copyright is fading. At the same time, the old self-help methods based on physical copying costs are as dead as Martial himself..$^{301}$ This Article argues that digital publishers' only remaining self-help option is to leverage the industry's comparative advantage in search.

Consider, for concreteness, an online digital bookstore where patrons can find and purchase books regardless of publisher. Whatever its limitations, the facility possesses one striking advantage compared to its brick and mortar predecessors. If it wants to, it can show each consumer an entirely different set of shelves and recommended titles. Exploiting this advantage gives online bookstores an enormous incentive to find books that consumers actually want.

How much revenue could a large digital bookstore extract from search? The answer depends on how many consumers (a) rely on the digital bookstore to discover new titles, and then (b) purchase the titles at marked up prices.

The first factor will normally depend on the store's comparative advantage in finding titles. To the extent this depends on search engines, a large digital bookstore should be able to provide better recommendations than any competitor. $^{302}$

300. First-mover advantages will normally encourage second-comers to avoid head-to-head competition in favor of variant products tailored to previously underserved users. See, e.g., Microsoft v. Commission of the European Community, Commission Decision 2007/53, 2007 O.J. (L 32) 23,23 (EC), available at http://eur-lex.europa.eu/legal-content/EN/TXT/? uri=uriserv:OJ.L_.2007.032.01.0023.01.ENG. This suggests that the original product will continue to earn above-normal returns.

301. See supra Part IV.C-D.

302. In the words of one recent FTC decision:

\footnotetext{
"More searches translate to more incoming data, which enables [the engine] to enhance the quality of the underlying algorithms used to process searches and match them to relevant advertisements. [The engine]'s search methodology and advertisement targeting become even better as consumers use [the] search engine more. Improved searches drive still more traffic to the site, which further increases the value to [the engine].
} 
However, human judgment is also important. To become dominant, a digital bookstore must find some way to merge automated search engine inferences with traditional editing judgments. Simply hiring human editors to adjust search engine rankings will not work; indeed, it would only revive the old Hollywood problem of deciding which experts were right. A much better strategy would be for the bookstore to buy editing judgments from outside firms. This can be done by showing publishers machine-generated rankings and letting them pay for the right to push favored titles higher up the list. ${ }^{303}$ Significantly, Google already sells ads this way. ${ }^{304}$

This kind of business model is bound to be controversial. Indeed, both the United States Federal Trade Commission and the European Commission have already investigated Google for adjusting machine rankings to make its own products more prominent. $^{305}$ While both proceedings were later dropped, ${ }^{306}$ this is hardly reassuring. The better answer is that publishers have always tried to outguess Martial's fickle market. Paying the digital bookstore to overrule machine-generated rankings is no different from investing money in advertising or complimentary copies. If the publisher guesses wrong, the book will never be popular and the publisher will lose her investment. If the publisher guesses right, the machine-generated rank was wrong from the start.

The fact that consumers can be persuaded to use a digital bookstore for search only matters if they stay long enough to buy books. This depends on how

Pamela Jones Harbour, Fed. Trade Comm'N, F.T.C. No. 071-0170, Dissenting Statement OF COMM'R HAROUR IN THE MATTER OF GOOGLE/DOUBLECLICK (2007) available at http:/www.ftc.gov/sites/default/files/documents/public_statements/statement-matter-

google/doubleclick/071220harbour_0.pdf. A Digital Bookstore would also enjoy scale economies in advertising and software development.

303. The scheme implicitly depends on consumers' well-documented willingness to accept rankings at face value. See, e.g., The Case for Fair Search, FAIRSEARCH.ORG, http://www.fairsearch.org/presentations/the-case-for-fair-search/ (last visited Oct. 4, 2014) (slideshow) (reporting that eighty-eight percent of Google users never look past the first three search results). Remarkably, this seems to be true even when consumers know that the list has been manipulated for decad.es.

304. Google's auction system sets per-click ad.prices equal to the next-highest bid. See Benjamin Edelman et al., Internet advertising and the Generalized Second-Price Auction, 97 AM. ECON. REV. 242, 242, 243 (2007).

305. FED. TRAdE COMM'N, F.T.C. No. 111-0163, Statement of the FEderal TRAdE COMMISSION REGARDING GOOGLE'S SEARCH PRACTICES 1 (2013), available at http://www.ftc.gov/sites/default/files/documents/public_statements/statement-commission-

regarding-googles-search-practices/130103brillgooglesearchstmt.pdf; Press Release, European Commission, Antitrust: Commission Probes Allegations of Antitrust Violations by Google (Nov. 30, 2010), http://europa.eu/rapid/press-release_IP-10-1624_en.htm?locale=en.

306. See FED. TRADE COMM'N, supra note 305, at 1; Joaqúin Almunia, Vice President, European Comm'n Responsible for Competition Policy, Statement on the Google Investigation (Feb. 5, 2014), http://europa.eu/rapid/press-release_SPEECH-14-93_en.htm. Regulators seem to have concluded that relief was impractical because there is no obvious way to tell when machinegenerated rankings have been tampered with. See FED. TRADE COMM'N, supra note 305, at 3-4. 
easily they can find cheap pirated editions elsewhere. ${ }^{307}$ We expect rational consumers to pay a per-title markup equal to:

(Markup) $=($ Predicted Number of Searches Needed to Find a Pirated Edition) $\mathrm{x}$ (Time per Search) $\mathrm{x}$ (Value of Time).

Assuming that readers earn the average US wage of $\$ 24.53$ per hour $^{308}$ and can investigate two "hits" per minute we have:

(Markup) $=($ Predicted Number of Searches Needed to Find a Pirated Edition) $\mathrm{x}(\$ 0.20)$.

The first term clearly depends on current search engine efficiency. However there is also a fundamental limit. This Article has argued that rational pirates are unlikely to copy every book. ${ }^{309}$ This guarantees that many searches will fail and that rational readers should always be willing to pay a markup.

This kind of self-help scheme is bound to be weaker than copyright. Most notably, our analysis depends on pirates' reluctance to copy every title. But consumers can be reasonably sure that bestsellers will be copied. This suggests that the digital bookstore's margin for trendy books will be small so that publishers will have much less incentive to find new authors. That said, the loss is smaller than it seems. Today's publishers re-invest most of their bestseller revenues in marketing blockbusters that the public already knows about. ${ }^{310}$ This is wasteful and contributes little to search. ${ }^{311}$

Our analysis suggests that a digital bookstore can extract substantial markups for the foreseeable future. In the long run, however, at least three threats are likely. First, this Article has argued that readers are more willing to search for illicit copies when piracy is common. ${ }^{312}$ This implies that each pirate's decision to copy a title benefits all pirates. Today's pirates are too small to capture this externality. However, a big pirate that published thousands of titles could capture the spillover. This would make copying even more

307. For convenience, we assume that the pirated copy is priced at cost. If the pirated copy is marked up, the digital bookstore's revenue would be correspondingly higher.

308. U.S. Dep't of Labor Bureau of Labor Statistics, Table B-3 (last modified Oct. 3, 2014), http://www.bls.gov/news.release/empsit.t19.htm.

309. See supra text accompanying note 297-298.

310. See ELBERSE, supra note 53, at 58.

311. See id. at 64, 66 (documenting industry trend toward concentrating more and more resources on fewer titles). One explanation for the effect is that the public sees advertising budgets as a quality signal. This creates an arm's race in which each publisher tries to buy more ads than his competitors. Like real arms races, the competition erodes profit while yielding very little social return.

312. See supra Part VII.A. 
profitable, increase the number of pirated titles, and further reduce the digital bookstore's markup. ${ }^{313}$

Second, self-help methods could also be undermined by improved search engines. Today's search engines force consumers to click through multiple "hits" before finding a pirated edition. But in the future, a single mouse click could suffice. This could be done by centralizing piracy in a single large pirate, launching a pirate bookstore that specialized in selling illicit editions, or investing in better search engines. The silver lining is that all of these piracy strategies introduce new scale economies and new chokepoints for regulation. This suggests that copyright's eclipse is only temporary.

Finally, pirates could find safe havens beyond the reach of American copyright law. So far, the Western world has limited overseas piracy through a combination of diplomatic leverage and holding host countries' appetite for Western brands and capital markets hostage. ${ }^{314}$ These levers are certain to erode as the West's share of world output shrinks. ${ }^{315}$ This may not matter if nonWestern intellectual property industries grow to the point where host countries have a bigger stake in enforcement. ${ }^{316}$ Failing that, the West's only recourse will be to build firewalls between rich nation consumers and foreign pirates. ${ }^{317}$ This is uncomfortably close to what countries like China and Iran already do for political reasons. ${ }^{318}$

\section{The Radical Solution: Replacing Editors}

So far this Article has assumed that effective search requires human judgment by experts. However, audience surveys and search engine methods could conceivably improve to the point where human editors become superfluous. This would probably require audience members to become much

313. A large pirate bookstore would perform the same function even if individual copyists remained small.

314. See, e.g., Kathy Chu \& Laurie Burkett, Alibaba Site Thrives, But So Do Knockoffs, WALL ST. J., Apr. 28, 2014, at A1, available at http://online.wsj.com/news/articles/ SB20001424052702304049904579517642158573008 (describing internet retailer Alibaba's efforts to remove counterfeit items from its website in order to attract U.S. investors).

315. See Suzanne Scotchmer, The Political Economy of Intellectual Property Treaties 5 (Nat'l Bureau of Econ. Res., Working Paper No. 9114, 2002), available at http://www.nber.org/papers/w9114.

316. See id. at 11.

317. Federal proceedings to seize copyright violators' domain names serve much the same purpose. Chris Hoofnagle (personal communication); See e.g. US Dept. of Justice, "Justice News: Federal Courts Order Seizure of 150 Website Domains Involved in Selling Counterfeit Goods as Part of DOJ, ICE HSI and FBI Cyber Monday Crackdown" available athttp://www.justice.gov/opa/pr/federal-courts-orderseizure-150-website-domains-involved-selling-counterfeit-goods-part-doj. An altemative strategy would instruct banks to block bank payments or declare debts to pirates unenforceable. Internet gambling legislation already uses this tactic. 31 U.S.C. $\S 5363$ (2012).

318. See generally Timothy B. Lee, Here's How Iran Censors the Internet, WASH. POST, Aug. 13, 2013, http://www.washingtonpost.com/blogs/the-switch/wp/2013/08/15/heres-how-irancensors-the-internet/ (describing how China and Iran implement online censorship). 
more involved than they are today. This section discusses how for-profit and open source institutions could persuade them to do this.

The 300,000 new titles published in English each year almost certainly include undiscovered gems. However, individual readers have a hard time finding them because uncoordinated search forces readers to plow through the same bad books over and over again. A commercial "Book Discovery Club" could overcome the problem by suggesting new books while screening out titles readers have repeatedly rejected in the past. Readers who allow themselves be managed in this way would almost certainly find better books than they could on their own. The Club could then gauge readers' reactions through some combination of explicit surveys and monitoring how quickly books were consumed.

In principle, readers should be willing to join a Book Discovery Club even if they have to buy books at retail. In practice, publishers would almost certainly subsidize promising titles as a form of marketing. These discounts would further bolster members' appetite for search.

Cash discounts and the inherent pleasure of reading are not the only way to motivate volunteers. Experience with open source software suggests that people also supply labor for "soft" reasons like inherent enjoyment, altruism, and a desire to impress others. ${ }^{319}$ Current initiatives that ask volunteers to remove errors from scanned e-books ${ }^{320}$ or create audio books from public domain texts $^{321}$ show that similar incentives can be mobilized for book production. There is also evidence that readers can be persuaded to donate editing judgment, most notably by identifying particularly attractive images ${ }^{322}$ and reviewing longforgotten books. ${ }^{323}$ While the per-person effort is usually small, ${ }^{324}$ this may not matter if enough people participate. The alternative is to encourage members who create resources for their own use to take the small additional step of

319. Stephen M. Maurer \& Suzanne Scotchmer, Open Source Software: The New Intellectual Property Paradigm in T. Hendershott (ed.), Handbook on Information Systems (Elsevier: 2006).

320. E.g., Front Page News \& Developments, DisTRIBUTED PROOFREADERS (last updated May 28, 2014), http://www.pgdp.net/c/. As of late 2014, about 28,828 books were complete with an additional 198 added in September 2014. Id. 1,364 volunteers had participated within the previous thirty days. Id.

321. E.g., LIBRIVOX: FREE PUBLIC DOMAIN AUDIOBOOKS, https:/librivox.org (last visited Nov. 17, 2014).

322. For example, Tumblr bloggers collect and post the images they like-sometimes from other Tumblr bloggers and sometimes new material from outside the community. See, e.g., Posts Tagged "Artcollection," TUMBLR.COM, https://www.tumblr.com/tagged/artcollection (last visited Nov. 17, 2014) (compilation of member-selected images).

323. Goodreads contributors write so many reviews that even obscure, forty-year-old bestsellers can receive more than a thousand entries. E.g., Reviews of The Last Convertible, GOODREADS.COM, http://www.goodreads.com/book/show/111831.The_Last_Convertible (last visited Nov. 17, 2014).

324. In at least one case, organizers ask volunteers to proof just one page per day. DISTRIBUTED PROOFREADERS, supra note 320. 
sharing it. ${ }^{325}$ Initiatives in which enthusiasts find and publish old-time radio recordings fit into this category. ${ }^{326}$ Therefore, it is hard to know which method would generate the most effort.

An open source initiative to find and rank order titles would be more challenging than any of these examples. In particular, leaders would have to show that they could screen out poor quality volunteers and direct manpower toward whichever books most needed review. For now, these seem like reasonable goals.

Finally, one can imagine business models that mix commercial incentives with voluntarism. In the software world, for-profit firms often interact with, and even subsidize, open source collaborations. ${ }^{32}$ At least one similarly cooperative model has already emerged in publishing. ${ }^{328}$ This suggests that publishers will eventually find it in their interest to support initiatives that discover and rank order book titles.

\section{CONCLUSION}

Legal scholars often assume that commercial publishing is synonymous with copyright. In fact, Roman and early modern societies constructed vigorous publishing industries with no formal protection at all. ${ }^{329}$ The real policy failing was that self-help evaporated after the first edition. This led to a disastrous conservatism that entrenched "classics" for hundreds of years.

The situation at the start of the twenty-first century is disturbingly similar. The fact that the new classics have names like Fast and Furious $7^{330}$ only adds insult to injury.

325. See infra note 326.

326. See, e.g., Adamelijah, Radio Spirits and the War on Old Time Radio Preservation, HUBPAGES.COM, http://adamelijah.hubpages.com/hub/Radio-Spirits (last updated July 3, 2011) ("The main reward is getting another half hour with one of your favorite shows. And if you're a generous soul, you're willing to share what you find with others...."). The main caveat in this example is that members almost always focus on finding episodes from shows that are already famous. Id. ("There's no big payoff waiting for the person who finds another episode of ninety-nine percent of the shows out there.").

327. Commercial software firms frequently donate money, software, and/or labor to open source initiatives. Stephen M. Maurer, The Penguin and the Cartel, 1 UTAH L. REV. 269, 272-73 (2012) (citing David S. Evans \& Richard Schmalensee, Some Economic Aspects of Antitrust Analysis in Dynamically Competitive Industries, in 2 INNOVATION POL'Y \& THE ECON. 1, 8 (Adam B. Jaffe et al. eds., 2002)). Students trying to learn a skill or attract the potential employers further augment this labor. Here, the existence of high wage jobs acts as a prize to elicit effort.

328. Companies that print on-demand books already pay fifteen percent of their profits back to the Gutenberg collaboration's open source book-scanning program. This directly benefits them by increasing the number of titles that consumers can order. Tredition Classics, "Literature Projects," available at http://www.tredition.com/projects (Tredition uses Gutenberg texts for 15,000 of its 100,000 titles and returns fifteen percent of its profits to the project).

329. See supra Part IV.C.

330. FAST AND THE FURIOUS 7 (Universal Pictures 2015). 
There are only three ways forward. First, publishers can try to shore up existing commercial models. This is unlikely to work for e-books, although it might suffice for movies and music. Second, commercial models can migrate to new institutions. This will almost certainly mean leveraging economies of scale in search. Finally, society can revert to the original Homeric model by collecting editing judgments directly from audiences. This will mean finding institutions that persuade consumers to transform themselves from essentially passive surveillance targets to active collaborators in search. 
Table 1: Second Century A.D. Egyptian Bestsellers ${ }^{331}$

\begin{tabular}{|c|c|}
\hline Authors & $\begin{array}{l}\text { Market } \\
\text { Share }\end{array}$ \\
\hline $\begin{array}{l}\text { Seventh century (601-700 B.C.). Homer (seventh or } \\
\text { eighth century B.C.) - } 17 \text { entries; Hesiod. (fl. } 650 \text { B.C.) - } \\
15 \text { entries; Archilochus (d. } 645 \text { B.C.) - } 6 \text { entries; Alcman } \\
\text { (fl. seventh century B.C.) }-3 \text { entries. }\end{array}$ & $11 \%$ \\
\hline $\begin{array}{l}\text { Sixth century (501-600 B.C.). Sappho (d. } 570 \text { B.C.) } \\
-5 \text { entries; Stesichorus (d. } 555 \text { B.C.) }-2 \text { entries. }\end{array}$ & $2 \%$ \\
\hline $\begin{array}{l}\text { Fifth century (401-500 B.C.). Euripides (d. } 406 \\
\text { century B.C.) }-21 \text { entries; Aeschylus (d. } 455 \text { B.C.) }-12 \\
\text { entries; Herodotus (d. } 425 \text { B.C.) }-9 \text { entries; Sophocles (d. } \\
405 \text { B.C.) }-9 \text { entries; Pindar (d. } 433 \text { B.C.) }-8 \text { entries; } \\
\text { Euphorion (fl. fifth century B.C.) }-3 \text { entries; Simonides } \\
\text { (d. } 468 \text { B.C.) }-2 \text { entries; Anacreon (d. } 485 \text { B.C.) }-1 \\
\text { entry; Bacchylides (fl. fifth century B.C.) }-1 \text { entry; } \\
\text { Ctesias (fl. 5th C. B.C.) - } 1 \text { entry; Hellanicus (d. } 405 \\
\text { B.C.) - } 1 \text { entry; Hipponax (fl. } 541 \text { B.C.) }-1 \text { entry; Strattis } \\
\text { (fl. fifth century B.C.) - } 1 \text { entry. }\end{array}$ & $19 \%$ \\
\hline $\begin{array}{l}\text { Fourth century (301-400 B.C.). Plato (d. } 347 \text { B.C.) } \\
-25 \text { entries; Demosthenes (d. } 322 \text { B.C.) }-24 \text { entries; } \\
\text { Thucydides (d. } 395 \text { B.C.) }-20 \text { entries; Aeschines (d. } 314 \\
\text { B.C.) }-12 \text { entries; Alcaeus (fl. fourth century) - } 11 \\
\text { entries; Aristophanes (d. } 386 \text { ) }-3 \text { entries; Antimachus (fl. } \\
400 \text { B.C.) - } 2 \text { entries; Aristotle (d. } 322 \text { B.C.) }-2 \text { entries; } \\
\text { Xenophon (d. } 354 \text { B.C.) }-2 \text { entries; Hyperides (d. } 322 \\
\text { B.C.) - } 1 \text { entry; Isaues (fl. fourth century) - } 1 \text { entry; }\end{array}$ & $28 \%$ \\
\hline
\end{tabular}

331. Survey based on the 386 second century literary documents described in the Table of Contents for the THE OXYRHYNCHUS PAPYRI (Vols. 1-67). Oxyrhynchus Online!, CENTER FOR THE STUDY OF ANCIENT DOCUMENTS, http://www.csad.ox.ac.uk/POxy/papyri/tocframe.htm (last accessed Oct. 15, 2014). The sample excludes (a) 443 second century documents containing nonliterary material like private letters, business correspondence, contracts, government edicts, and court proceedings, (b) documents that cannot be unambiguously assigned to the second century, and (c) 83 entries describing catalogs, glossaries, commentaries and other secondary documents that describe underlying literary works. Including the last group would have increased the dominance of Homer and the classics in our sample even further. Finally, the Table of Contents sometimes contains two or more entries for pages that were originally part of a single document or cache. This effect seems to be small. 


\begin{tabular}{|c|c|}
\hline Lycurgus (d. 323 B.C.) - 1 entry. & \\
\hline $\begin{array}{l}\text { Third century (201-300 B.C.). Callimachus (d. } 240 \\
\text { B.C.) - } 20 \text { entries; Theocritus (fl. third century B.C.) }-11 \\
\text { entries; Apollonius Rhodius (fl. third century) - } 9 \text { entries; } \\
\text { Menander (d. } 290 \text { B.C.) }-8 \text { entries; Satyrus the } \\
\text { Peripatetic (fl. third century B.C.) }-2 \text { entries; Dinarchus } \\
\text { (d. } 291 \text { B.C.) }-1 \text { entry; Aratus (d. } 240 \text { B.C.) - } 1 \text { entry; } \\
\text { Conon (d. After } 394 \text { B.C.) }-1 \text { entry; Lycophron (fl. third } \\
\text { century B.C.) }-1 \text { entry; Philaenis (third or fourth century } \\
\text { B.C.) - } 1 \text { entry; Theophrastus (d. } 287 \text { B.C.) }-1 \text { entry. }\end{array}$ & $15 \%$ \\
\hline $\begin{array}{l}\text { Second century (101-200 B.C.). Heraclides Lembus } \\
\text { (fl. second century B.C.) - } 1 \text { entry; Nicander (fl. second } \\
\text { century B.C.) - } 1 \text { entry. }\end{array}$ & Less than $1 \%$ \\
\hline $\begin{array}{l}\text { First century B.C. (1-100 B.C.). Strabo (d. } 24 \text { A.D.) } \\
-1 \text { entry. }\end{array}$ & Less than $1 \%$ \\
\hline $\begin{array}{l}\text { First century A.D. (1-100 A.D.). Gospel of Matthew } \\
\text { (ca. } 80-90 \text { A.D. }-2 \text { entries); Letter to the Philippians (62 } \\
\text { A.D.) }-1 \text { entry. }\end{array}$ & Less than $1 \%$ \\
\hline $\begin{array}{l}\text { Second century A.D. (1-200 A.D.). Gospel of John } \\
\text { (ca. } 200 \text { A.D.) - } 1 \text { entry; Achilles Tatius (fl. second } \\
\text { century A.D.) - } 1 \text { entry; Babrius (fl. second century A.D.) } \\
-1 \text { entry; Pancrates (fl. } 149 \text { A.D.) - } 1 \text { entry; Phlegon (fl. } \\
\text { second century A.D.) - } 1 \text { entry; Plutarch (d. } 120 \text { A.D.) - } 1 \\
\text { entry. }\end{array}$ & $2 \%$ \\
\hline $\begin{array}{l}\text { Unknown. Unknown or Unlisted Authors - } 75 \\
\text { entries. Authors who lack complete Wikipedia entries - } \\
\text { Gnomai Monstichoi ( } 1 \text { entry), Anoubion ( } 1 \text { entry), } \\
\text { Aristodemus ( } 1 \text { entry), and Mythographus Homericus ( } \\
\text { entry). }\end{array}$ & $21 \%$ \\
\hline
\end{tabular}


